\title{
SULPHUR AND PYRITE.
}

\section{THE COVE CREEK SULPHUR BEDS, UTAH.}

\author{
By Wilus T. Lee.
}

\section{GENERAL STATEMENTS.}

Location.-The sulphur deposits here described are owned by the Utah Sulphur Company, of Salt Lake City, and are located in central Utah, at Sulphurdale, a small mining camp about 20 miles north of Beaver, Utah, the nearest important town. The camp is not permanent and is deserted during the winter or whenever mining operations cease. The deposits are situated about 4 miles south of the site of old Cove Fort and are locally known as the Cove Creek sulphur beds. They are conveniently reached by team from Beaver, but the railroad connection or shipping point is Blackrock, a station on the San Pedro, Lós Angeles and Salt Lake Railroad about 24 miles northwest of Sulphurdale.

Occurrence.-The sulphur extends from the surface downward to a , considerable though unknown depth in beds of soft rhyolitic tuff and varies in amount in different parts of the beds. An area of several acres has been exploited, the sulphur having been mined more or less continuously for 30 years, but the lateral extent as well as the depth of the deposits is unknown.

Neighboring deposits. - There are several more or less widely separated deposits of sulphur in the vicinity of Sulphurdale, ranging in a general northeast-southwest direction. One deposit 3 miles north of the camp is said to have been worked to some extent, but the other prospects have not been developed, although they are said to show indications of considerable quantities of sulphur.

\section{GEOLOGY.}

Formations.-The Paleozoic sediments of the plateau region probably occur at a considerable depth beneath the surface at Sulphurdale. Their nearest exposures are at the north end of Mineral Mountains and in the Beaver River range to the west, where they dip eastward beneath the extrusive rocks which cover the surface. 
The Tushar Mountains, near the north end of which the sulphur beds occur, are composed of eruptive rock consisting, so far as examined, of flows, breccias, and tuffs of rhyolite overlain in places by andesite. Much of the tuff is soft, fine-grained, and snowy white. The rhyolites presumably rest upon sedimentary rocks, as in neighboring regions, and are apparently several thousand feet thick. The sulphur occurs in the white tuff, which some of the miners call "gypsum."

In the vicinity of Sulphuirdale basalt overlies the rhyolites and andesites in slightly eroded flow sheets and crater cones. Two conspicuous cones having well-defined craters occur near the sulphur beds, one about 10 miles to the southwest, the other 3 miles west of the camp. Still other cones and associated flows are situated farther north, forming a linear group lying essentially parallel to the neighboring mountain ranges. The fresh appearance of the lavas and the slight amount of erosion of the cones indicate recent formation, and lavas of similar character near Blackrock rest upon the Bonneville beds, from which fact it seems probable that the cones were formed during late Quaternary time.

Structure.-There are reasons for believing that the sulphur beds are located in or near a zone of intense faulting and volcanic activity and that the conflicting forces causing the disturbances-have not yet reached a state of equilibrium. Evidence of this is found not only in the vicinity of Sulphurdale, but for long distances both north and south of this place:

Along the western border of the high plateaus of Utah, from St. George northeastward, several basins have been formed by faulting, accompanied orfollowed by the movement of large crust blocks. Rush Lake Valley and Parowan Valley are perhaps the most conspicuous of these basins. The strata of the plateau to the east lie essentially horizontal, while those to the west dip eastward beneath the valleys. In the Beaver basin this simple relation is complicated by the great masses of effusive rock which cover the sediments, but west of the basin, in the vicinity of Minersville, and again at the north end of Mineral Range, the Paleozoic sediments appear underneath the effusives, dipping eastward beneath the basin. From this it is inferred that Beaver Valley, like those farther south, is due to crustal movement and that the great fault zone which follows the western margin of the plateau through Rush Lake and Parowan valleys, and along which displacements of thousands of feet are known to have occurred, probably continues through Beaver Valley, and thence northeastward past Sulphurdale.

Several phenomena noted mark this zone as one of recent disturbance. The line of sulphur beds, from which hydrogen sulphide is still escaping in large quantities, and less exactly the line of the recent 
volcanic cones, coincide with it or lie parallel to it. The region between St. George and Fillmore is known as a zone of frequent and severe earthquakes, several shocks of sufficient force to destrow buildings having occurred there within the memory of men still living in this vicinity.

\section{SULPHUR.}

\section{CHARACTER OF ORE.}

Some of the sulphur occurs in cylindrical masses or cores 10 or 15 feet in diameter, having a rude radial structure, as. if they had been formed about a central vent that extended downward into the beds of tuff, but it occurs mainly as a dark-colored impregnation or cementing substance in the rhyolitic tuff. In certain places it appears as irregular veins of nearly pure yellow sulphur ramifying through the beds. These veins, some of which are several inches thick, are usually banded parallel to the walls and are evidently filled fissures. The sulphur is apparently deposited in some way from solution, since in several places acid water, an analysis of which is given below, was found issuing from small fissures partly filled with yellow sulphur. Here and there a small cavity is lined either with flowers of sulphur or with sulphur crystals.

The ore varies greatly in richness; at some places there is only a trace, at others there are masses of practically pure sulphur. Samples taken at the extremities of the workings have been analyzed by E. C. Sullivan, of the United States Geological Survey, and found to contain, respectively, 80 and 65 per cent of sulphur. The first sample was taken from a horizontal sheet 8 feet thick and the second from a vertical dikelike body 4 feet thick. There is a large quantity of equally rich ore and much that is not so rich. Material having as low as 15 per cent of sulphur, however, is considered paying ore.

The cost of production is doubtless much greater than it would be if the mining were done on a scale sufficiently large to warrant the installation of modern machinery. The stripping to a depth of 10 feet or more is done entirely by horses and scrapers, much of the material having been moved several times, and the ore is removed by manual labor, whereas both operations might easily be performed with steam shovels at greatly reduced cost.

At the smelter the ore is placed in iron retorts and the sulphur melted out by steam, which is forced into it under a pressure of about 60 pounds, representing a temperature of $144^{\circ} \mathrm{C}$. The melted sulphur finds its way to the bottom of the retort and is drawn off into iron receptacles, in which it cools and hardens into cakes weighing about 200 pounds each. In this form it is stored until needed, when it is ground into flour and sacked for shipment. The rate of extraction is slow, but experience has shown that an attempt to hasten it by raising 
the temperature of the steam results in diminishing the output and in some cases has almost wholly stopped the process. The steam pressure employed varies somewhat with the kind of ore. Cedar wood, which grows in abundance in this vicinity, is used as fuel.

The sulphur as it comes from the retort has been analyzed by Herman Harms, State chemist of Utah, who reports the composition as follows:

Analysis of sulphur from retort at Sulphurdale, Utah.

Sulphur

99.71

Nonvolatile residue (silica, iron oxide, etc.) $\ldots \ldots \ldots \ldots \ldots \ldots \ldots . .23$

Free sulphuric acid ............................... Trace.

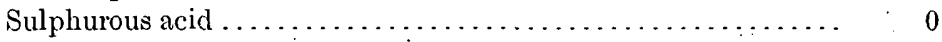

Arsenic......................................... 0

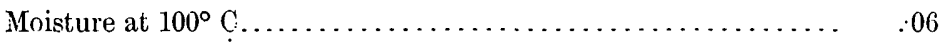

100.00

ORIGIN.

Several facts noted seem to point clearly to the mode of origin of the sulphur. The geologic relations, previously stated, indicate that the deposits are on or very near a fault line and are closely associated with volcanic rocks. The presence of a recently extinct volcano to the west, the flows from which extend within about a mile of the sulphur beds, suggests that the sulphur may have resulted from the eruptions of this volcano. Gas is now escaping here in large volumes; in some places through vents suggesting those supposed to have given rise to the cylindrical cores of sulphur; in other places through thousands of small jets from the porous beds of tuff, giving rise to the general dissemination of the sulphur through the beds. Wherever water stands in the excavations the gas boils up through it at short intervals. No sulphur dioxide $\left(\mathrm{SO}_{2}\right)$ was noted, but the disagreeable odor of hydrogen sulphide $\left(\mathrm{H}_{2} \mathrm{~S}\right)$ was strongly perceptible. The occurrence of large quantities of hydrogen sulphide suggests that this gas is the source of the sulphur. When it comes into contact with oxygen in the porous tuff near the surface it is probably oxidized, losing its hydrogen and dropping the sulphur as expressed by the simple formula:

$$
\mathrm{H}_{2} \mathrm{~S}+\mathrm{O}=\mathrm{H}_{2} \mathrm{O}+\mathrm{S} \text {. }
$$

The sulphur being a solid remains where it is set free in the porous tuff. If this explanation is correct, continued oxidation would form a certain amount of sulphur trioxide $\left(\mathrm{S}+3 \mathrm{O}=\mathrm{SO}_{3}\right)$, which in combination with water forms sulphuric acid $\left(\mathrm{H}_{2} \mathrm{O}+\mathrm{SO}_{3}=\mathrm{H}_{2} \mathrm{SO}_{4}\right)$. It is a matter of interest in this connection to observe that the water issuing from the beds is strongly charged with acid, as shown by the following analysis made by W. M. Barr, of the United States Geological Survey: 
Analysis of water from Cove Creek sulphur beds.

\begin{tabular}{|c|c|}
\hline \multicolumn{2}{|c|}{ [Parts per million.] } \\
\hline Dissolved solids at $180^{\circ} \ldots \ldots$. & 8,816 \\
\hline Dissolved solids at $130^{\circ}$. & 10,810 \\
\hline Suspended matter........ & 52 \\
\hline Silica $\left(\mathrm{SiO}_{2}\right) \ldots \ldots \ldots \ldots$ & 1.24 \\
\hline Ferrous oxide $(\mathrm{FeO}) \ldots$ & 560 \\
\hline Ferric oxide $\left(\mathrm{Fe}_{2} \mathrm{O}_{3}\right) \ldots$ & 802 \\
\hline Aluminum (Al) ........ & 0 \\
\hline Calcium (Ca)........ & 158 \\
\hline Magnesium ( $\mathrm{Mg})$. . & 232 \\
\hline Sodium (Na) \} & \\
\hline Potassium $(\mathrm{K})\} \cdots \cdots$ & .144 \\
\hline Carbonate radicle $\left(\mathrm{CO}_{3}\right) \ldots$ & 0 \\
\hline Bicarbonate radicle $\left(\mathrm{HCO}_{3}\right)$ & 0 \\
\hline Sulphate radicle $\left(\mathrm{SO}_{4}\right) \ldots \ldots$ & 7,602 \\
\hline Free sulphuric acid $\left(\mathrm{H}_{2} \mathrm{SO}_{4}\right)$. & 4,523 \\
\hline Chlorine (Cl) $\ldots \ldots \ldots . . . \ldots$ & 79 \\
\hline Nitrate radicle $\left(\mathrm{NO}_{3}\right)$. & \\
\hline Free sulphur (S)..... & \\
\hline
\end{tabular}

No'te.-Constant loss of dissolved solids occurs when heated above $130^{\circ}$. Heated at $180^{\circ}$ not constant. Sample had free hydrogen sulphide $\left(\mathrm{H}_{2} \mathrm{~S}\right)$ when collected, with possible presence of sulphur dioxide $\left(\mathrm{SO}_{2}\right)$.

The veins filled with yellow sulphur and the cavities lined with crystals or flowers or sulphur might be interpireted as indicating that the sulphur came up in melted or vaporized condition. The quantity occurring in this way, however, is very small compared with that contained in the tuff, and may be due to some secondary action.

\section{CONCLUSION.}

The facts and inferences regarding the occurrence and origin of the Cove Creek sulphur deposits may be summarized as follows:

There are valuable deposits of sulphur not only at Sulphurdale, where it is being extracted, but at several other localities in the same neighborhood. The Cove Creek sulphur beds have supplied the local market for about thirty years, their average annual output being estimated at 1,000 tons. The sulphur is probably the result of volcanic action; as is shown by its presence in a volcanic region where recent eruptions have occurred. It is presumably derived from hydrogen sulphide, which is still escaping in large quantities, and its concentration in the beds of rhyolitic tuff is probably due to the general dissemination of the gas through the porous material near the surface, - where it comes in contact with oxygen which unites with the hydrogen to form water, leaving the sulphur as a cementing substance in the loose material. The process of formation and concentration is apparently active at the present time. 


\section{SURVEY PUBLICATIONS ON SULPHUR AND PYRITE.}

The list below includes the important publications of the United States Geological Survey on sulphur and pyrite:

Avams, G. I. The Rabbit Hole sulphur mines, near Humboldt House, Nev. In Bulletin No. 225, pp. 497-500. 1904.

Davis, H. J. Pyrites. In Mineral Resources U. S. for 1885; pp. 501-517. 1886.

Eckes, E. C. Gold and pyrite deposits of the Dahlonega district, Georgia. In Bulletin No. 213, pp. 57-63. 1903.

- Pyrite deposits of the eastern Adirondacks, N. Y. In Bulletin No. 260, pp. 587-588. 1905.

Martin, W. Pyrites. In Mineral Resources U. S. for 1883-8.4, pp. 877-905. 1886. Richardson, G. B. Native sulphur in El Paso County, Tex. In Bulletin No. 260, pp. 589-592. 1905.

Rothwhli; R. P. Pyrites. In Mineral Resuurces U. S. for 1886; pp. 650-675. 1887.

Spurr, J. E. Alum deposit near Silver Peak, Esmeralda County, Nev. In Bulletin No. 225, pp. 501-502. 1904.

490 


\section{N D E X.}

A.

Abrasive materials, papers on....

Survey publications on, list of.

Page. 438-447 Acme Glass Sand Company, quarry of ... 367-368 Adami, Mr., aid by ..................... 31 Adams mine, N. C., description of ....... 416-417 section of, figure showing............. $\quad 416$

A kron, Ohio, glass sand at............ 367,374

Akron White Sand Company, quarry of... 374

Alabam a, clays of, paper on............. 291-295 geologic section in ................... 153 glass sand in ...................... 377 iron making in.................... 159 iron ores in, analyses of... 135, 154, 176, 177, 178 origin of................. 149, 178-181 paper on .................... 161-184 production of .............. 150-151, 159 work on................ 20-21,130-184

limestone and dolomite in, work on.. 247-255 sand-lime brick making in, work on .. 256-258 Alabama-Virginia Iron Ore Company, mines of...................... 158

Alaske, work in, reference to reports on....

Albion Kaolin Company, Ga., clay beds worked by ............. 311-312

Allegheny formation, clays in........... $337-$ $339,342,345,347-348,353$

section of 336

Allen, O. D., analysis by................. 209

Alum Creek, N. Mex., alum rock from, analyses of .................. 219

Alum deposits along Gila River, paper on. 215-223 Alum rock, analyses of .................. $\quad 219$

Aluminum ores, Survey publications on.... 224 work on.................... 23, 215-223

Alunogen, analyses of ................. 220

Alunogen Ridge, N. Mex., alum rock from, analysis of

American Clay Company, Ga., clayss worked o by ........................

American Phosphorus Company, mine and works of ............475,482

patents of..................... 480-481

American Window Glass Company, quarry of ........................ 369

Analyses. See names of substances.

Andeluvia Mountain, Ala., iron ore in, occurrence of.............. 168,171

Anderson, Robert, and A rnold, Ralph, paper by, on diatomaceous deposits in Santa Barbara County, Cal ............. 438-446

work of
Andrews, J. K., coal bank of, clay at..... 338

Androscoggin River, pegmatites on ....... 384

Apatite, extraction of phosphorus from.... 474

A rizona, bauxite deposits in, work on..... 23

metalliferous ores in, work on......... 16

Arkansas, aluminum ores in, work on...... 23

geology of........................ 465

glass sand in....................... 378

analysis of ...................... 382

manganese in .................... $466^{\circ}$

phosphate deposits in. See Lafferty Creek, Ark.

section in ........................... 46

Arkansas Fertilizer Company, history of . $467-468$ Arkansas Phosphate Company, organization of ................... 467

Arnold, Ralph, and Anderson, Robert, paper by, on diatomaceous deposits in Santa Barbara County, Cal............. 438-446

work of ........................... 25

Ashley, G. H., cited on Tertiary deposite of Indiana ....................

Atlanta Mining and Clay Company, beds worked by................. 307

Auburn, Mc:, feldspar at................ 391-392

Augusta, Ga., glass works at............ 378 Austin, W. I., paper by, on nickel ores from Oregon, reference to......... 120

B.

Bacorn, F. W. and I.L. C., aid by .......... 31

Balaam Brothers, quarry of.............. $\quad 440$

Baldauf No. 1 mine, Pa.; shale at.......... 337 Ball, S. H., paper by, on copper deposits in

Wyoming................. 93-107 paper by, on graphite in Haystack Hills,

Wyo................... 426-428 on Hartville iron-ore range, Wyo. 190-205 on mica in the Hartville uplift, Wyo.................. 423-425

on Portland cement materials in eastern Wyoming........... 232-244

on titaniferous iron ore of Iron Mountain, Wyo............. 206-212 work of.......... 19, 22, 23, 24, 25, 190, 206, 232

Bangor limestone, analyses of . . ...... 158, 248, 249 description of ..................... 247-249 sections of.......................... 248

Banister, J. R., work of ................ 225

Barr, W. M., analysis by................. 488

Barrs Mill, Ohio, glass sand at.......... 374 
Bastin, E. S., paper by, on feldspar and Page. quartz of Maine. ........... 383-393

paper by, on feldspar and quartz of southeastern New York. . . . 39 394-399

work of . . . .

Bates, P. H., anulyses by............ 234, $235-236,237,238,297,340$

Batesville, Ark., phosphates near....... 467

Bauxice, deposits of, work on ........ 23,215

Survey publications on............. 224

Bay Point Landing, Me., feldspar near.... 389

Bear Lake, Utah, phosphates near...... 450,461

Bear Lake Plateau, Utah, structure in.... 453

Beaver, Utah, sulphur near. . ......... 483

Bedford, N. Y., feldspar near. ........... . 394-399

feldspar near, analyses of........... 396

Beeson, J. L., analysis by ................ 249

Bell, R. N., cited on gold mining along Snake River...................

cited on platinum in Snake River placers.

quoted on gold of Snake River diggings.

Bennington, Idaho, phosphates near.......

Berkey, C. P., and Eby, J. H., cited on copper in Minnesota.............. 101

Berks County, Pa., magnetite in....... 185-189

Berry, A. R., quarry of ................. 392 .

Beyer, S. W., analytical work in charge of. . 225

Big Bend country, Wash., geography of ... 56-57

geology of. . . . . . . . . . . . . . . . . 58-60

topography of ................ 57-58

Big Ridge mine, N. C., description of.... 409-410

Big Sioux River, Iowa, glass sand on ..... 379

Big Spring, Ala., geologic section at....... 139

Bioticie, occurrence of . . . . . . . . . . ....... 406

Bimetallic Mining Company, operations and

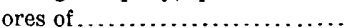

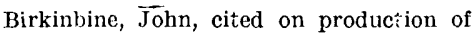
iron ores in Alabama.........

Birmingham district, Ala., clays of, paper on.

geology of. ..................... 132-134

iron ores of, paper on ........... 130-151

limesione and dolomice in, paper on. . 247-255

mining costs in, compared with those in

Talladega Counıy............ 184

sand-lime brick making in, paper on. 256-258

topography of . .............. 130-132

Birmingham Sand-lime Brick and Stone Manufacturing Company, plant of, notes on.......... 257-258

Birmingham Testing Laboratory, analyses by .......................

Birmingham Valley, Ala., Paleozoic rocks in, section of ................

Blake, W. P., cited on Gila River.alum deposiis............ 215,221-222, 223

Black Gap, Pa., clay beds near.......... 325

Black Hand, Ohio, glass sand at....... 367

Black Hand formation, use of, for glass

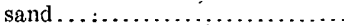

Black sands of Columbia River, mineral composition of. Blackfoot, Idaho, gold diggings near. ......
Blacklick Creek, Pa., clays and shules near. . . . . . . . . . . . . . . 352-353

Blissard, Charles, acknowledgments to.... 330

Blount Springs, Ala., quarry at, limestone from, analysis of. ............ 248

Blue Bur, Columbia River, gold-bearing gravels at................ 66

Bon Homme tunnel, Colo., rocks cut by... . 28

Boone chert, description of........... 467

Boothbay Harbor, Me., pegmatíes near... 384

Borax, Survey publications on .......... 267

Boisford, G. C., acknowledgments to...... 190

Boutwell, J. M., work of................ 15

Brainerd, A. F., analysis by ............ 176

Bradley, Wyo., limestone near, analyses

of . . . . . . . . . . . . . . . . . 241,242

shale near, analyses of ........... 242, 243

Bradley, F. H., quoted on placer gold on Snake River.............. 76

Branner, J. C., quoted on Arkansas phosphates.................. 464-465

Branner, J. C., and Newsom, J. F., cited on Arkansas phosphates....... 471, 472

Bravo, José J., cited on occurrence of vanadium in carbonaceous deposits . $\quad 116$

Britton, J. B., analysis by............ $\quad 176$

Brookville clay, occurrence of ........... 337

Brown, W. Q., acknowledgments to...... 120

Building stone, work on ................ 24

Building sione and road metal, paper on. 356-359

Survey publications on, liš $\tilde{\imath}$ of ........ 360

Burchard, E. F., paper by, on brown iron ores near Russellville, Ala... 152-160

paper by, on Clinton iron ores of Birmingham district, Ala....... 130-151

on glass-sand industry of Indiana, Kentucky, and Ohio ........ 361-376

on various glass sands.......... 376

on Portland cement materials near Dubuque, Iowa........... 225-231

on southern red hematite as ingredient of metallic paint ....... 430-434

work of .............. 20,24, 25, 130,225, 247 Burton Mesa, Cal., diatomaceous earth on. 441-442 Butts. Charles, paper by, on clays of Birmingham district, Ala...... 291-295

paper by, on limestone and dolomite in Birmingham district, Ala . . . 247-255 on sand-lime brick making near Birmingham, Ala........... 256-258

work of . . . . . . . . . . . . . . . . .

Butler, Ga., clay beds near........... 313-314 Buxton formation, use of, as glass sand.... 379

\section{C.}

Cable mine, Mont., history of ......... 32,45 geology of $\ldots \ldots \ldots \ldots \ldots \ldots \ldots \ldots \ldots .47-49$ ore deposits at. . . . . . . . . . . . . . . . 49-55 operations at . . ................. 46-47 California, diatomaceous earth in, anaiyses of $\ldots \ldots \ldots \ldots \ldots \ldots \ldots \ldots \ldots \ldots .445$

diatomaceous earth in, deposits of, work on ................. 25

description of ................ 438-439 distribution of ............ 440-445, 447 
California, diatomaceous earth in, geologic Page.

distomaceous earth in, production of .. 446

See also Diatomaceous earth.

magnesite deposits of, work on.........

metalliferous ores in, work on..........

Calkins, F. C., cited on geology of part of

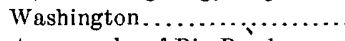

cited on topography of Big Bend country in Washington...........

section of sedimentary rocks in Philipsburg quadrangle supplied by ... 33-34

work of $\ldots \ldots \ldots \ldots \ldots \ldots \ldots \ldots \ldots \ldots \ldots \ldots \ldots \ldots, 31$

Calkins, F. C., and Smith, G. O., cited on geology of part of Washington..

Campbell, B. H., quarry of, section at.....

Campbell, M. R., work of, reference to......

Caney Fork, N. C., mica on...............

Canton Tile Hollow Brick Company, clay pit of, section in ............ 338

Carboniferous rocks, phosphates in... 449, 451-452 use of, for glass making ........... 365,367

Carlisle, $\mathrm{Pa}$., clay beds mined near...... 322-334

Carnotite, deposits of, in Colorado, paper

on...................... 110-117

Carolina gneiss, mica in ............... 403-404

Carson, J. P., analysis by.............. 209

Casmalia, Cal., diatomaceous earth near. .443-444

Cason shale, descripition of ............ 466

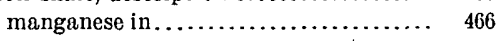
phosphates in .................. 466

Cassville, Wis., geologic section near...... 226

Cathance, Me., feldspar at........... 390-391 feldspar mills at . . . . . . . . . . . $387-390$

Catlett, Charles, cooperation with........ 268

Cattail Branch mine, N. C., description of. 410-411

Caywood claim, Colo., carnotite deposits at....................... 113-114

Cebada Canyon, Cal., diatomaceous earth in . . . . . . . . . . . . . . . $442-443$

Cement resources, work on.............. 23

Cements, Survey publications on . ...... 245-246 work on ..................... 225-244

Central Silica Company, quarries of...... 373

Chalfants, Ohio, glass sand at.......... 367, 373 glass sand at, analysis of ........... 376

Chalk rock. See Diatomaceous earth.

Champion Shaft, Colo., rocks and ores at... 28-29

Chandler, C. F., analysis by ........... 176

Chander mine, Minn., copper at........... 101

Charter Oak copper prospects, Wyo., rocks and ores at.................

Chattanooga, Tenn., glass works at...... 378

Chattanooga Paint Company, ores of, analysis of.................. 434

Cheltenham, Mo., clay resources at..... 315-321.

Cheney Marble and White Lime Company, quarry of, limestone at, section of . . . . . . . . . . . .

Chepultepec, Ala., quarry at, limestione at, section of ...................

Cheyenne, Wyo., vicinity of, discussion of, as site for Portland cement plant................... 239-244

Chickamauga limestone, analyses of...... 251
Page.

Chickamauga limestone, description of . . 250-252

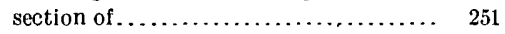

Childersburg, Ala., magnetite near, analyses of .................... 176

Chink Knob prospect, N. C., description of. $\quad 416$ section of, figure showing.......... 416 Chromium, Survey publications on, list of.. 129 Chrysoprase, occurrence of, in Oregon...... 124 Chugwater Creek, Wyo., iron ore from, analysis of ....................

Citizens' Coal Company, mine of, clay from, analysis of ................. 348

Clarion clays, occurrence of . . . . . . . . . $337-338$

Clarion Junction, Pa., clay near......... 341

Clarion quadrangle, Pa., clays and shales in, paper on............. 335-343

Clark mine, N. Mex., clay from, analysis of $\ldots \ldots \ldots \ldots \ldots \ldots \ldots \ldots . \ldots \ldots$

Clarke, F. W., analyses by...... 123, 126, 220, 221 paper by, on nickel ores from Oregon, reference to............... 120

Clarkville, N. Mex., clay from, analysis of.. 300 Clay, analyses of . ... 230, 272, $307,308,310,311,312$, $313,314,325,340,347,348,351,352$

bleaching power of. ................ 286 papers on ..................... 268-355

Alabama.................... 291-295

Colorado.................... 296-302

Georgia..................... 303-314

Missouri ................... 315-321

New Mexico . . . . . . . . . . . . . . . . 296-302

Pennsylvania.................. 322-334

Survey publications on ............. 355

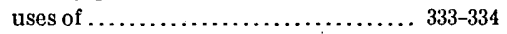

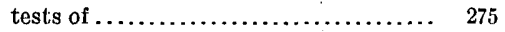

work on .......................... 24

Clays and clay products, papers on...... 208-355

Clays and shales, Cambria County, Pa., pa-

per on.................... 344-354

Clarion County, Pa., paper on....... 335-343

Clay beds, Missouri, sections of. ........ 317-318

Clayton, Mo., section of clay beds near.... 317

Clements, J. M., cited on copper in mines of Minnesota ................. 101

Cleveland tunnels, Colo., country rock and mineralization at............. 28

Clinton iron $0: 39$, mining of .......... 430-431

origin of $\ldots \ldots \ldots \ldots \ldots \ldots \ldots \ldots \ldots \ldots \ldots \ldots .149$

paper on ...................... 130-151

use of, in paint making . . ........... 430

Coal Creek district, Colo., geology of. .... . 112-113

Coaldale, Ala., section at .............. 293

Cokeville, Wyo., phosphates near . . ... 456-457

section near, figure showing .......... 456

Collier, A.J., paper by, on gold-bearing river sands of northeastern Washington................... $56-70$

work of . . . . . . . 19

Colloids, absorption of organic coloring matter by ................ 285, 287

definition of ....................... 280

presence of, in fuller's earth . . . . . . . 280-282

properties of . . . . . . . . . . . . . . . . . 281-282

Colorado, carnotite in, paper on........ 110-117 gold and silver deposits in, report on ... 26-30

Bull. 315-07-32 
Page.

Colorado, work in, on metalliferous ores.... 16-17

Columbia River, black sands of, mineral composition of ............... 61

gold placers of .................... $60-70$

distribution and amount of gold in. 70

former work on .................. 56

gold of, origin of ................ 69

methods of mining................ 69

sections of ...................... $62-68$

.upper part of, geology of region near.... 58-60

topography of region near......... 57-58

Columbia Engineering Works, analysis by . 209

Columbiana, Ala., hematite near, analyses of......

Columbiana Mountain, Mla., iron ore in, occurrence of............... 173

section on..................... 173-174

Colville Indian Reservation, gold placers in, investigations of ............. 56-70

Comey, A. M., cited on colloidal clay........ . 280

cited on minerals in fuller's earth..... 269-270

Compton, Ala., mine at, sections of iron-ore seam at.................... 145

quarry at, limestọne from, analyses of.. $\quad 249$

Conasauga limestone, analyses of......... $\quad 255$

description of ..................... 254-255

Condit, P. B., analyses by............... 177

Conemaugh formation, clays in......... 344,

$345,346-347,351-352$

section of ........................ 346

shales in ................. 346,349,351-352

Confer, A. V., coal bank of, clay at........ 338

Cope, E. D., quoted on gypsum in New Mexico .......... 260-261

Copper, papers on ................... 93-107

Survey publications on, list of........ 108-109

Copper Belt Mines Company, Wyo., mines and prospects of ........... 105-107

Copper Bottom prospect, Wyo., rocks and ores at.

Copper mines of Hartville uplift, Wyo., figure showing.................. 192

Copper ore, occurrence of, in Maine....... 118-119

Corey, G. H., analysis by ................ 220

Cornwall type, magnetite deposits of, in Pennsylvania, paper on ...... 185-189

Cottonwood Canyon, Wyo., mica near ..... 423

Cove Creek, Utah, sulphur beds at, geology of ....................... 483-487

sulphur beds at, location of............ 483 ore of, character of .............. 487-488

origin of ...................... 488-489

paper on...................... 483-489

sulphur from, analyses of........ 488-489

Coward Mountain mine, N. C., description

of . ..................... 414-415

Cox \& Davies mine, N. C., description of .... 415

Coxville, Ind., glass sand at...... 365,366,367-368

glass sand at, analysis of............. 376

Crafts, W., analyses by.................. 176

Crampton, C. A., and Simons, F. D., qunted on fuller's earth........ 279-280,284

Crawford Mountains, Wyo., structure in... 453

Cretaceous sandstones, use of, as glass sand ..................... 378-379

Creve Cœur Lake, Mo., clay beds near..... 320
Page.

Cross, Whitman, work of................ 10

Cross, Whitman, Howe, Ernest, and Ransome, F. I., cited on Silvertion mining district............... 26

Crowell, B., analyses by................. 177

Croydon, Utah, phosphates near......... 450

Crystal Palace claim, Wyo., description of.. $\quad 424$

Cryolite, Survey publications on .......... 224

Cullowhee, N. C., mica near............... 415

Cumberland Clay Company, Pa., operations of ...................... 326-327

Cumberland Valley, Pa., geology of ........ 476 Cunningham Gap, Ala., geologic section at. 144-145 Cushman, A. S., cited on colloids and pectoids..........................

cited on effect of water on rock powders................ 271,281,283

quoted on absorption of basic ions of electrolyte by pectoid matter... 282

Cushman, Ark., phosphates near......... 467

Cyrus Shepard mine, Pa., clay at......... $\quad 347$

D.

Dakota sandstone, use of, for glass sand.................. 378-379, 381

Dale, Ala., geologic section near........... 145

quarry at, limestone at, section of ..... 248

Dale, ' $\boldsymbol{T}$. N., paper by, on New England granites................. 356-359

work of ......................... 24

Dana, J. D., cited on fuller's earth . . 268-270,276

Dariington, Ala., quarry near, limestone from, analyses of ............ 158

Darton, N. H., cited on geology of Newcastle, Wyo., and vicinity...... 233

Darton, N. H., and Smith, W. S. T., eited on Guernsey formation........ 102

Davis gold diggings, Snake River, Wyo., operations at.............. $77-78$

Dawson, E. M., jr., acknowledgments to... 291 work of .......................... 247

Day, D. T., cited en electric reduction of iron ores......................... 212 quoted on black sands of Snake River. 78 ,

Day, D. T., and Richards, R. H., cited on black sands of Snake River..... 78

De Soto, Ala., section at............... 291

Deitz, Lewis, farm of, clay on............ 338 Des Peres River, Mo., clay deposits near.. 316 319 Devonian sandstones, use of, for glass sand. 365 Devonian shales, phosphates in.......... 464

Dewey, F. P., analẏsis by ................ 176

Diatomaceous earth, imports of .......... 447

paper on ....................... 438-446

production of .................... 446-447

properties of ........................ 445

uses of ............................ 446

work on deposits of ................. 25

See also California, diatomaceous earth in.

Diller, J. S., work done in conjunction with.. 120 Dilltown, Pa., clay near, analysis of....... 352 Dolomite in Birmingham district, Ala., paper on............... 247-255 
Driftless Area, residual clay and loess from, a nalyses of ................ 230 Dry Branch, Ga., clay deposits on.... 306-309,314 Dubuque, Iowa, geologic section north of.. loess from, analysis of.

Portland cement materials near, paper on .................... 225-231

Dundee, Ohio, glass sand at............. 374 glass sand at, analysis of ............ 376

Durango-Gallup coal field, clays of, paper on..................... 296-302

Durango Pressed Brick Company, operations of.................. 297-298

E.

Eakle, A. S., cited on mincrals in fuller's earth .................... 269-270

Earth, diatomaceous. See Diatomaceous earth.

Eby, J. H., and Berkey, C. P., cited on copper in Minnesota............. 101

Eckel, E. C., cited on analysis of Bangor limestone.................. 248,249

cited on cost of Portland cement plant. .

cited on gypsum in New Mexico........

paper by, on investigations of iron ores, structural materials, etc........

on mineral-paint ores of Lehigh Gap, Pa................. 435-4337

work of, reference to................ 7

Eckel, E. C., and Burchard, E. F., report on Birmingham iron ores to be prepared by....................

Economic geology, work in, reports of, form and titles of ...................

El Jaro Creek, Cal., diatomaceous earth on. .

Eldridge, G. H., cited on geology of Coal Creek district, Colo.

Electricity, use of, in reduction of iron ores. .

Elk City, Pa., clay near.................

Ely, Nev., copper district at, work in...... 17

Emauhee mine, Ala., description of..... 167-168 ores of, analyses of ................ 177

Emmons, S. F., cited on origin of copper ores..........................

field work of ........................ report by, on investigations of metalliferous ores............... 14-19

Emmons, W. H., paper by, on GraniteBimetallic and Cable mines, Mont..................... 31-55 work of .......................... 17-18

Empire mine, Wyo., copper ores at....... 98-99 Estelle, Ga., paint ore at............... 432 paint ore at, analysis of ............ 432 section of ......................... 432

Europe, phosphorus in, production of...... 481 Everett (E. H.) Company, quarry of..... 372-373 Everhard Company, quarry of . ......... 373-374 Everhart, E., analyses by .............. 307, $308,310,311,312,313,314$ F.

Fairbanks, H. W., cited on diatomaceous earth.......................
Fairmount, Pa., shale near..............

Fall River, Kans., glass sand near . . ..... 380 glass sand near, analysis of.......... 312 limestone at, analysis of ............ 380

Fallston, N. C., mica near............... 414

-Fayetteville, Pa., clay beds near.......... $\quad 325$

Feldspar, analyses of .................. 396 deposits of, work on ................ 24 manufacture of ................... $387-388$ mining of . . . . . . . . . . . . . . . 389-393, 394-394 uses of ......................... 386-387

Feldspar and quartz, deposits of, Maine, paper on .................. 383-393 deposits of, New York, paper on .... 394-399 papers on....................... 383-399

Fenneman, N. M., paper by, on clay resources of the St. Louis district.................... 315-321

Fernando formation, diatomaceous earth in .......................439,444

Ferrier, W. F., and Weeks, F. B., paper by, on phosphates in West...... 449-462

work of .......................... 25

Fishersburg, Ind., glass sand near. ..... 364-365 Flatwoods formation. See Conasauga limestone.

Florida, glass sand in .................. 378

Floyd River, Iowa, glass sand on . . ...... 378-379

Folios, geologic, character of ............ 9 list of, showing mineral products described...................... 9-13

Foullon, H. B. von, analysis by ......... 123 cited on nickel ores of $O$ regon . ........126, 127 paper by, on nickel ores from Oregon, reference to................. 120

Fossick quarry, near Darlington, Mla.., limestone from, analyses of . .... 158 Fox River, Ill., glass sand of, marketing of.. 3363 Frunkfort, Ky., glass works ut......... $3(3,370$ Franklin, Pa., clay near............... 347 Franklin gold diggings, Snake River, operations at................... 80

Fredonia, Kans., glass sand near. ......... $\quad 379$ section near.................... 379 F reeport clays, occurrence of..... $339,342,347,351$ Frostburg, Pa., clay near............... 342 Fuller's earth, analyses of ........... 271-272, 277 base of $\ldots \ldots \ldots \ldots \ldots \ldots \ldots \ldots \ldots \ldots . .282$ composition of ..................... 289-290 geology and origin of ................ 268-278 minerals in ................... 269-270, 290 natiure of ....................... 276-290 properties and tests of, paper on ...... 268-290 structure of...................... 283,288 Survey publications on .............. 355 tests of......................... 273-275 Fusz, P. A., aid by .................. 31

G.

Gale, H. s., paper by, on carnotite in Colorado...................... 110-117 work of ........................... 17 Galena, Ill., loess from, analysis of ........ 230 Gallina, N. Mex., gypsum at............. 262 Gallup, N. Mex., clay industries near.... 299-301 
Gardner, J. H., and Shaler, M. K., paper by, on clays of Durango-Gallup coal field..................... 296-302

Gate City, Ala., glass sand at........... 377 glass sand at, analyses of........... 382 quarry at, limestone from, analyses of. . 251

Geologic folios, character of .............. list of, showing mineral products de-

scribed.................... 9-13

Georgetown, Idaho, phosphates near ..... 461

Georgetown, Me., feldspar at........... 389-390

feldspar at, analysis of .............. 390

Georgia, Cretaceous rocks in, map showing exposures of .................. glass sand in...................... 378 hematite in, geologic relations and development of . . ........... 431-432

mining of ...................... 430-431

use of, in paint................ 430 iron ores of, work on ........... 21,430-432 kaolins and fire clays of, paper on.... 303-314 Georgia Kaolin Company; clays worked by.. 308 Genthite, analyses of ................. 123-124 Gerry, J. A., quarry of ................. 392 Gibson, Ga.. clay beds near . . . . . . . . . . . 310-311

Gila River, alum deposits along, paper on . 215-223 alum deposits along, sketch map of .... 218 alunogen from, analyses of.......... 220 halotrichite from, analyses of ......... 221

Glass-making materials, papers on...... 361-382 work on ......................... 24

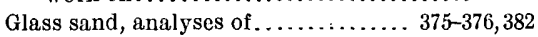

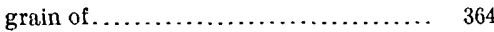
occurrence of .............. 364-375,377-381 preparation of................... 363-364 production of ..................... 362-363 qua rries for ....................... $367-375$ work on ........................ 24

Glàss-sand industry of Indiana, Kentucky, and Ohio, paper on .......... 361-376

Glass products, character and value of .... 361-362

Glass works, locations and descriptions of.. 362

Glasser, - cited on origin of nickel ores. .. $\quad{ }_{0} 127$

Gold and silver, papers on............... 26-88

Survey publications on . ............. 89-92

Gold Hill shaft, Wyo., copper ores in...... 105

Golding Sons' Company, quarry of........ 389

Good Fortune mine, Wyo., production of . . 193

Goodwin, F. M., work done in conjunction with . . . . . . . . . . . 50

Gordon, Ga., clay deposits near.......... 309-310

Göthite, occurrence of................ 154-155

Graneros shale, analyses of ......... 234, 237, 242 occurrence of....... 234-235, 236-237, 242, 243

Granite-Bimetallic mine, Mont., geology of. 38 history and development of .......... 36-38 ore deposits at................ 38-45,54,55 vein in, section showing............. 42 workings at, sketch plan of........... 39

Granite mine, Mont., operations at....... 33

Granite Mountain mine, Mont., operations. and ores at. ............... 36-37

Granite Railway Company's quarry, granite of, composition of .......... 358

Granites, shades of, cause of............ 358 recent work on ................... $359-360$
Page.

Graphite, analyses of ................. 427 deposits of, work on ................ 25 Hartville uplift, Wyo., localities of, figure showing............. 192 Haystack Fills, Wyo., paper on..... 426-428 Graphite, mica, etc., papers on .......... 400-429 Survey publications on, list of ......... 429

Graton, I. C., cited on pegmatites........ 420,422 work of . . . . . . . . . . . . . . . . .

Graves, Ala., section at................ 293 Gray Ore Iron Company, operations of ... 164-168 Guyon, Ark., glass sand at.............. 378 Green Hope mine, Wyo., copper ores at .. 102-104 Green Mountain Boy copper mine, Wyo., ores at.................. 97-98

Greenspring mine, Alı., sẹction of iron-ore seams in .................. 142-143

Grimsley, G. P., cited on plasticity of clays 280-281 Grout, F. F., cited on plasticity of clays ... 273 Guernsey formation, Wyo., copper deposits in................. 97-98, 102-105 description of .................. 194-195, 203

Gypsum, analysis of ................... 264 New Mexico, paper on............. 260-265 outcrop of, sketch map showing.... 261 Survey publications on, list of......... 266 work on.

$24,260-265$

H.

Haanel, Eugene, quoted on electric reduction of iron ores............ 212

Hall, Edwin, acknowledgments to ........ 93

Halotrichite, analyses of............... 221

Harbord, F. W., quoted on electric reduction of iron ores...............

Harrell, W. F., quarry of, limestone at, section of.

Harris Canyon, Cal , diatomaccous earth in and near...................... 443

Harrishurg, Pa., wavellite near......... 474

Harrishurg Clay Company, Pa., operations of.........................

Hartville, Wyo., copper mines near, production of ................. 94

copper deposits near, report on....... 93-107

Hartville formation, description of...... 195, 203 Hartville iron-ore range, Wyo., geography of ....................... 191 geology of ........................ 193-196 production of ........................, 193 report on ...................... 190-205 Hartville uplift., Wyo., copper deposits in. . 93-107 economic map of .................. 192 mica in . . . . . . . . . . . . . . . . . . $42 ; 3-425$

Haworth, Erasmus, cited on origin of copper ores................... 101

Haws, A. J., \& Sons, mine of, clay from, analysis of .................. 348

Jawthorn, Pa., clay ne凤r............. 338-339 shale near...................... 337

Hawthorn Pottery Company, clay used by $\ldots \ldots \ldots \ldots \ldots \ldots \ldots \ldots \ldots .338-339$

Hryes, C. W., field work of ............. 23,216 introduction by .................. $7-13$ paper by, on Gila River alum deposits $2 \mathrm{i}$ - -223 
Page.

Haystack Hills, wyo., graphite in . . . . . 426-428 iron ores in ..................... 205

Haystack Peak, Wyo., copper ininerals at. . 97 ITeacock Mountain, Ala., iron ores of, analyses of . . . . . . . . . . . . . 176, 177 prospects on, description of . . . . . . 168-170

Febron, Me., feldspar near. . . . . . . . . . . . 392-393 pegmatite at................... 384

Hell Gate Bar, Wash., gold-bearing sands at .......................62-63

Heidrick, C. F., farm of, clay on ......... 341

Hematite, mining of . . . . . . . . . . . . . . 430-431 occurrence of

134-146,

$174-178,197,198-199,203,204,205$ origin of . . . . . . . . 179-181, 197-198, 200-201

use of, in paint. ................. 430-434

Henry Clay, Pa., clay deposits near . . 327, 331-333

Hephzibah, Ga., clay beds near...... 311-312, 314

Herrick, H. N., cited on gypsum in New Mexico.

Hess, F. L., work of . ..................

Hewett, Foster, cited on occurrence of vanadium in carbonaceous deposits

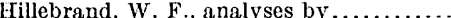
quoted on coal as a source of vanadium.

Hillebrand, W. F., and Ransome, F. I., quoted on carnotite of Colorado.

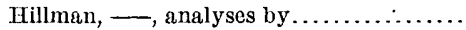

Hobbs, W. H., citedon copper in Minnesota.

Hobby, Albert, quarry of . . . . . . . . . . . . 398

Hobby quarries, N. Y., feldspar from . . . . 398-399

Hodges, R. S., analyses by ............ 178

Hoffer, I. L., information furnished by . . 78, 79, 80

Holland, Ohio, glass sand at . . . . . . 367, 371-372 section $a t$, record of .............. 372

Holmes, J. A., acknowledgments to....... 232

Hood, Doctor, analyses of nickel ore by.... 123

Hope Hill, Mont., discovery of ores at .....

Hopkins,'T. C., cited on clays of South Mountain, Pa....... 322, 324, 325, 327, 334 quoted on Izard limestone.......... 465

Horace Thompson mine, N. C., description of . . .................... 411-412

Hot Springs, Idaho, phosphates at...... 461

Howard, Mike, farm of, clay on.......... 341

Howe, Ernest, Cross, Whitman, and Ransome, F. L., cited on Silverton mining district..............

Hoyer, Peter, acknowledgments to........ Huey, Pa., cliay at. ................... 338 Hudson schist, occurrence of . . . . . . . . 394-395 Hulst, N. P., cited on production of titaniferous iron ores in Sweden....

\section{I.}

Idaho, geology of southeastern part of . . 450-454 gold placers in . ................ 80-86 phosphates in, description and geology

of . . . . . . . . . . . . 449.454

occurrences of . . .

section in . . . . . . . . . . . . . . 450-451

structure in .................... 453-454

Illinois, glass sand of, marketing of ...... 363
Illinois l3oy mining prospect, Colo., operations and ores cut by ......... 28 Indiana, glașs-making materials in . . . . 361-363, $364-366$

glass-making materials in, analyses of. 376 glass products................. $361-362$ glass-sand quarries in . . . . . . . . 362, 366-369

Mansfield sandstone in . . . . . . . . . 365-366 Indiana Geological Survey, maps and reports of . . . . . . . . . . 366 Indiana, Kentucky, and Ohio, glass-sand industry of, paper on......... 361-370 Infusorial earth. See Diatomaceous earth.

Iowa, cement resources of, work on....... 23 glass sand in.................... 378-379 Portland cement materials in, work on 225-231 Iowa College of Agriculture and Mechanic Arts, analytical work at....... 225

Iowa Geological Survey, cooperation of.... 225 Iron Mountain, Wyo., geography of. ... . 206-207 geology of. ................... 207-210

titaniferous iron ore of, paper on.... 206-212 Iron ores, analyses of..... 135, 154, 176, 177, 178, 209 beds containing, description of ..... 139-144, $154-155,166-174,196-205$ sections of .................. 141-144, 145 production of, in Alabama......... 150-151. sections of Rockwood formation containing............. 136-139, 144-145

Survey publications on, list of...... 213-214 work on.................. 20-22, 130-212 Irondale, Ala., geologic sections near.... 136, 141 Iverson, B. A., work done in conjunction with ................... 71 Izard limestone, description of ...... 465-466, 473

J.

Janes, W. E., analysis by . . . . . . . . . . . 255

Johnson mine, N. C., mica in ............ 409

Johnstown, Pa., brick and clay industry near, statistics of .......... 353-354

clays and shales near.............. . 346-350

Johnstown Pressed Brick Company, plant of, section at................. 346

Johnstown quadrangle, Pa. See Cambria County.

Jones, - - cited on diffusion of colloids as compared with crystalloids.... 282

Julian Gap, Tenn., paint ore near....... 433-434

\section{K.}

Kahatchee Hills, Ala., iron ore in, occurrence

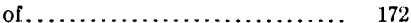

Kaolin, analyses of ... 307, 308, $310,311,312,313,314$ paper on.................... 303-314

Kansas, glass sand in................. $379-380$ glass works in. ................. $\quad 379$ Katala Hills, Ala., iron ore in, occurrence of $\ldots \ldots \ldots \ldots \ldots \ldots \ldots \ldots \ldots .172-173$

Kay, G. F., paper by, on nickel deposits of Nickel Mountain, Oreg...... 120-127 work of . ........................ 18

Kelley, W. T., acknowledgments to....... 93 
Kemp, J. F., cited on iron ores near Iron Mountain, wyo............... 200

Kenneth, Ind., glass sand ncar.......... 364 Kentucky, glass-making materials in.... $364-360$ glass-making materials in, analyses of.: $\quad 376$ glass-sand quarries in........... 363,369-370 Kentucky, Ohio, and Indiana, glass-sand industry of, paper on......... 361-370 Kentucky Silica Company, quarry of. .... 369-370 Ketona, Ala., quarry at, dolomite from, analysis of ....................

Killbuck, Ohio, glass sand at............. Kindle, E. M., quoted on Wolcott quarry. . Kinkle quarry, N. Y., feldspar from, description of ................. 395-398

feldspar from, value of.............. 398

quartz from..................... 397

Kittanning clays, occurrence of....... 338-339, $345,347,348,351,353$

Klondike, Mo., glass sand of, marketing of.. $\quad 363$

Knight, W. C., analysis by ............... 209

cited on copper output of Sunrise mine, Wyoming.

report by, containing references to copper deposits in Wyoming, reference to ........................

Knox dolomite, analyses of................ description of .................... 252-254

Kohler, Ernest, cited on origin of copper ores..........................

Krümmel \& Büchner minẻ, section at...... Kunz, G. F., cited on occurrence of chrysoprase in Oregon................

I.

I A K ranch, Wyo., limestone near, analyses of .........................

La Belle tunnel, Colorado, operations and country rock at................

La Zaca Creek, Cal., diatomaceous earth on ........................ 442-443

Labrea Creek, Cal., diatomaceous earth on.. Ladd, G. E., quoted on hydrosilicates of aluminum

Lafferty Creek, Ark., phosphate deposits at, age of ........................

phosphate deposits at, analyses of...... bibliography of ................... descriptions of ............. 467-471,473 geography and history of........ 463-465 geology of................... 465-467 origin of ................... 471-472 prospecting for .............. 472-473 section of ..................... 469 workings at.................... 471

Lake Fork extension of Silverton mining area, Colorado, paper on....... 26-30

Lake View, Ala., section of iron-ore seams near........................

Laurel Forge, $\mathrm{Pa}$., clay beds at............

Layland, Ohio, glass sand at.............

glass sand at, analysis of ............. 370

Lead, Survey publications on, list of. ....... 128

Lead ore, Maine, occurrence of.......... 118-119

Leavittsburg, Ohio, glass sand at......... 375

Lebanon County, Pa., magnetite in...... 185-189
Page.

Ledoux, A. R., paper by, on nickel ores from Oregon, reference to.......... 120

Lee, W. T., paper by, on Cove Creek sulphuir beds.................... 483-489

work of ............................ 25

Leeds, Ala., cement plant at. .......... 251-252

Lehigh Gap, Pa., mineral paint of, analyses

of ....................... 437

mineral-paint ores at.............. 435-437

character and analysis of ......... 430

manufacture of ................ 436-437

section ut......................... 435

Leith, C. K., work of ................. 22

Lesquereux, Leo, cited on Evanston deposits.................... 73

Lewis, A. W., work of ................. 225

Lime, limestone available for, work on.... 23-24 Survey publications on.............. 259 work on ..................... 247-258 Limestone, Birmingham district, Ala., paper on ................. 247-255 work on....................... 23-24

Limonite, occurrence of. ...... 154-155, 197, 204, 205 origin of .................... 180-181, 198 Lincoln, Nebr., glass sand near........... 381

Lindgren, Waldemar, cited on copper deposits of Clifton-Morenci district, Arizona................ 53 work of $. \ldots \ldots \ldots \ldots \ldots \ldots \ldots \ldots \ldots \ldots, 15,10-17$

Linebarger, C. E., on retention of salts by pectoids.................. 282

Lines, E. F., paper by, on clays and shales in Clarion County, Pa....... 335-343

Lipari Islands, Italy, volcanic ash from.... 440

Little Gravois Creek, Mo., glass sand on.... 380

Little Rock, Ark., fertilizer plant at....... 468 Littlefield, Me., feld spar mills at..... 387, 391, 392 Lodge, A., acknowledgments to ........... 255

Loess, analyses of ...................... 230

Lompoc, Cal., diatomaceous earth near... 440-441 Lone Pine Gap, Ala, section of iron-ore seams near................. 142 Loogootee, Ind., glass sand at . . ..... 365, 368-369 glass sand at, analysis of............ 370

Loogootee Glass Sand Company, quarry of ...................... $368-369$

Lookout sandstone, possible use of, for glass sand ................... 378

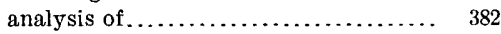
Lovick, Ala., section at................. 293 Lucas limestone, use of, in glass making.... 371 Lucky Henry incline, Wyoming, copper ores in..................... 105 Lyle Cut mine, N. C., description of...... 412-413

M.

McCall, Charles, farm of, clay on.......... 338

McCalley, Henry, analysis by ........... 176 cited on analysis of Bangor limestone.. 158 cited on analyses of brown iron ores.... 154 cited on iron ore at Andeluvia Mountain. 168 cited on stratigraphy of Russellville district, Ala.............. 152-153

McCanns Pass, Wyo., graphite at....... $426-428$ mica near.......................... 423 
McCartney, Wis., section of PlattevilleGalena beds near.............. 229

McCoy Creek, gold diggings on........... 79

McCreath, A. S., analysis by............. 177

MacDonald, D. F., work of.............. 31

McIntyre, Ga., clay deposits near........ 309-310

McKinney mine, N. C., description of ...... 409

McQueen, C. B., farm of, clay on.......... 341

farm of, clays from, analyses of....... $\quad 340$

Malthacite, analysis of.................. 276

Magne-Silica Company, quarry of.......... $\quad 440$

Magnesia, Survey publications on ......... 259

work on deposits containing........... 24

Magnesite, work on................ 24, 247-258

Magnetite, deposits of, in Berks and Lebanon counties, $\mathrm{Pa}$., paper on... 185-189 occurrence of........ 174-175, 185-189, 197, 208 origin of ........................ 179-181

Maguire \& O'Heron quarry, granite of, composition of ............... 358

Maine, feldspar of, availability of. ....... 388-389 manufacture of ................ $387-388$ mining of ..................... 389-393 occurrence of.................... 393 uses of . ........................ 386i-387

feldspar and quartz deposits of...... 383-393 granites of, work on ............... $356-357$ mineral prospect in, note on.......... 118-119 pegmatites of, character of.......... 385-386 composition of.................. 383,385 distribution of .................. 383 geologic ocćurrence of. ........... 383-384 origin and age of..................... 385 uses of ........................ 386-387 quartz of, manufacture of ............ 388 mining of . . . .................. 389-393 uses of . ....................... 386-387

Maine Feldspar Company, mills of. ...... 387, 391 quarry of ......................... 391

Mancos shale, analyses of. .............. 297, 300

Mandle, I., \& Co., Georgia, clay beds worked by ........................ 309

Manganese, occurrence of ............... 466,473

Manganese ores, Survey publications on. . 213-214 work on................... 22-23, 130-212

Mansfield sandstone, occurrence and character of .............. 365-366, 368

use of, for glass sand .............. 365,368

Market Lake, gold diggings near......... 79

Martin, Lawrence, and Phalen, W. C., paper by ...................... 344-354

Massachusetts, granites of, work on ...... 357-359 Massillon, Ohio, glass sand at....... 367, 373-374 analysis of ......................... 376

Massillon Sand and Stone Company, quarry of .......................... 374

Massillon sandstone, use of, for glass sand ............... 367,373-374

Matches, use of phosphorus for......... 482-483 Maumee, Ohio, glass works at............ 371 Mechanicsville, Pa., clay near........ 338, 341, 342 Meissner, _ —, analysis by............... 177 Mercer clays, occurrence of ............. 337, $339,345,348-349,350-351$

Mercer shales, occurrence of ........... 349-350 Merom sandstone, occurrence of . ........ 366
Mesa Blanca Capulin, N. Mex., geologic section in ..................... 262 Mesaba mine, Ala., description of........ 165-167 ores of, analyses of.............. 177, 178

Metz, Henry, acknowledgments to........ 93 Mica, deposits of, investigations of...... 24-25, $400-422,423-425$ deposits of, North Carolina, paper on. 420-422 North Carolina, publications on, list of ....................... 401

Wyoming, paper on ............ 423-425 prospects of, figure showing.... 192 mining and treatment of . .......... 417-418 origin of ........................ 418-422 uses of ........................... 400

Mica, graphite, etc., papers on ......... 400-428 Survey publications on, list of........ 429

Michael, L. G., analyses by ............. 228, 229 Miller clays. See Kittanning clays.

Millport, Pa., mineral-paint ore near.... 435-436 Milton, Mass., granite of, composition of... 358 Milton English mine, N. C., description of $\ldots \ldots \ldots \ldots \ldots \ldots \ldots \ldots \ldots \ldots+407-409$

Mineral paints, materials available for, work on ......................... 25

papers on ..................... 430-4.37 Mineral-paint ores of the I.ehigh Gap, Pa., paper on................... 435-4:37

Mineral resources of U.S., annual report on, form and character of .......... 13

Minnekahta limestone, analyses of ..... 235, 242 occurrence of................. 235,241-242

Minnesota, copper mines in, ores of....... 101 Minnie claim, Wyo., description of........ 425 Missouri, clay resources in, paper on..... 315-321 glass sand in..................... $380-381$ marketing of .................... 363

Missouri River, glass sand on ........... $\quad 379$

Mitchell, L. J., mine of, clay at............ 347 Monroe formation, use of, for glass sand... 367,370 Montana, gold and silver deposits in, work

- on ........................ 31-55

work in, on metalliferous ores........ 17

Monterey formation, diatomaceous earth in . ................ 439-441, 444-445

Monticello lode, Colo., operations, ores, and general features at............ 27-28

Montpelier, Idaho, phosphate beds near.. 457, 461 phosphate beds near, section of, figure showing.................. 459 section near, figure showing.......... 458 Montpelier Creek, Idaho, phosphates on.. 458-459 Morrell, T. T., analyses by............ 347, 348, 351 . Morrison shale, analysis of ............... 236 occurrence of .

Moss brick works, De Soto, Ala., section at.. 291 Mount Apatite, Me., feldspar at ........ 391-392 Mount A rarat, Me., feldspar at............ 391 Mount Holly Brick and Clay Company, $\mathrm{Pa}$, operations of .............. 330-332

Mount Holly Springs, $\mathrm{Pa}$., clay beds mined near ..................... 322-334

phosphorus ore at, discovery and development of .............. 474-476 geology of . .................. 476-477 origin of ................. 477-478 
Mount Mica, Me., pegmatite workings at... 384 gems in .................... 385

Mountai" Creek, Pa., clay beds along... . . 323-332 Mowry, C. W., farm of, clay on .......... 341 Muscovite, occurrence of . . . . . . . . . 406, 423-424 Myers, James, farm of, clay on......... 338 N.

Nantahala Mountains, N. C., mica in.... 411, 412 Napoleon shaft, Colo., rocks and ores cut by. National Sand and Stone Company, quarry of . ..................... 374-375

Natural cement. See Cements.

Nebraska, glass sand in .............. 381 Nespelem Bar, Wash., gold prospects at... 62

Nevada, phosphates in............... 450 work in, on metalliferous ores. . . . . . 17-18

Newark, Ohio, glass works at.......... 373

Newberry, J. S., cited on gypsum in New Mexico................... 260

New Bethlehem, Pa., clay near......... 337-338 clay near, section of ................ 338

New Caledonia, nickel ores from, analyses of. 123 Newcastle, Wyo., discussion of, as site for Portland cement plant...... 232-239

Portland cement materials near, distribution of, map showing...... 233

shale near, analyses of . . . . . . 234, 237, 238 New England, granites of, recent work on, paper on ................. 356-359 New England Granite Works, granite of, composition of ................ 359

New Hampshire, granites of, work on. . . 357-359 New Jersey, iron ores of, work on........ 22

New Mexico, alum deposits in, paper on. - 215-223

gypsum in, work on ............. 260-265

Newsom, J. F., and Branner, J. C., cited on Arkansas phosphates....... 471,472

New York, feldspar of. ............... 394-399

feldspar of, analyses of............ 396

New York claim, W yo., deseription of. .. . 424-425

Niagara sandstones, use of, for glass sand. 364-365

Nickel, deposits of, at Nickel Mountain, Oreg., paper on . . . . . . . . 120.127 Survey publications on, list of........ 129

Nickel Mountain, Oreg., geology of region near...................... 121-122 mining operations at.............. 121 nickel ores at .................. 120-127 origin of . .................. 125-127

Nickel ores, analyses of . . . . . . . . . . . . 123 occurrence of, in Oregon............ 120-127

Niles, Ohio, glass sand at. ......... 367,374-375

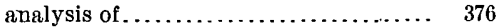

Niles Fire Brick Company, farm of, clay on . 341

Niobrara limestone, analysis of ......... 241 occurrence of . ................... 240-241

Nordenskiöld, A. E., cited on occurrence of vanadium in carbonaceous deposits.

North Birmingham, Ala., glass sand at... glass sand at, analysis of ....................... quarry at, dolomite from, analysis of. . North Carolina, mica deposits of, character of.
North Carolina, mica deposits of, distribntion of . . . . . . . . . . . . . 402-403 Inica deposits of, geologic occurrence of. . . . . . . . . . . . . . . . . $403-407$ mines of . . . . . . . . . . . . . 407-417 mining of .............. 401,417-418 origin of . . . . . . . . . . . . . $418-422$ - production of ................... 400 work on .................... 24-25

pegmatites in, gems in ............. 407

mica in ................... 400-418

minerals in . ................... 407

occurrence of . . . . . . . . . . . 405-406

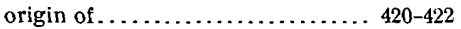
rainfall and elimate in............... 403

North Castle, N. Y., feldspar at. . . . . . . . 398 North Valley Hill, Pa., wavellite on....... 475

0.

Obalski, J., cited on occurrence of vanadium in carbonaceous deposits...... 116

Ohio, glass-making materials in . . . . . 361-363,367 glass-making materials in, analyses of. $\quad 376$ glass products of . . . . . . . . . . . . . . 361-363 glass-sand quarries in. . . . . . . 362,370-375 Ohio Geological Survey, maps of ........ 367 Ohio, Kentucky, and Indiana, glass-sand industry of, paper on . . . . . 361-376 Ohio mine, Colorado, operations, country rock, and ore at.......... 29-30 Ohio River formation, usc of, for glass sand . . . . . . . . . . . . 366,369

Ohio Stone, Cement and Construction Company, quarries of .......... 371-372

Oil tests of fuller's earth and other materials, tables showing........ 273-875

Ojo del Espiritu Santo, N. Mex., geologic section near................ 264

O. K. tunnels, Colorado, operations at.... 30 Olivine, analysis of . . . . . . . . . . . . 126 Oklahoma, copper deposits in, reference to. 101 Omaha incline, Wyo., copper ores in ...... 105 Ooltewah, Tenn., paint ore at, analysis of.. 433 Ore Bank station, Pa., shale at........ 337 Orcutt, Cal., diatomaceous earth at....... 444 Oregon, nickel ores in ............. 120-127 work in, on metalliferous ores........ 18 Ottawa, Ill., quarry methods at........ 370 Ostwald, —, cited on colloids........... 280 Owensboro, glass works at............. 363 Oxmoor sandstone, use of, for glass sand .. $\quad 377$

$$
\text { P. }
$$

Pahasapa limestone, analysis of . . . . . . 235-236 occurrence of . . . . . . . . . . . . . $235-236$

Paints, mineral, papers on.......... 430-437 use of hematite in ............... 430-434

Paper making, use of clay for.......... 333 Park View mine, Colo., operations and ores at $\ldots \ldots \ldots \ldots \ldots \ldots \ldots \ldots \ldots . .27$

Pćctoids, definition of ................. 280 presence of, in fuller's earth. . . . . . . 280-282 properties of . . . . . . . . . . . . . . . . 281-282 Pegmatites, composition and character of. . 383. $385-386,394,405-406,422$ 
Page.

Pegmatites, geologic occurrence of ..... 383-384, $394-395,403-404$ $400-418,423,425$

mica in.

origin of $\ldots \ldots \ldots \ldots \ldots \ldots \ldots \ldots \ldots \ldots .418-420$
sections of, tigures showing......... 413,416

Pendleton, Ind., glass sand near......... 365

Pennsylvania, clays in. paper on........ 322-334 clays and shales in, work on........... $335-354$ iron ores of, work on ............... 22 magnetite in, work on.............. 185-189 mineraı paint ores of. See lehigh Gap, Pa.

phosphorus ore in. See Mount Holly Springs, $\mathrm{Pa}$.

Pensacola, Fla., glass sand at............

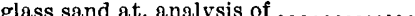

Peppel, S. V., cited on cost of making sandlime brick.

Peridotite, analysis of..

Peru Township, Iowa, limestone and shale from, analyses of.

Perry, Ga., clay beds near

$312-313$

Phalen, W. C., and Martin, Lawrence, paper by, on clays and shales in Cambria County, Pa............ 344-354

Philadelphia Clay Company, clay beds worked by .............. 322, 324,327

operations of .................... 327-330

Philipsburg quadrangle, Mont., general geology of ................ 33-35

ore in, distribution and character of.... 35 ore production of .................... 33

report on ore deposits in ............ 31-55

Phillips, A. J., analyses by ............. 234, $235,237,238,241,242,243$

Phillips, W.' B., analyses by ........... 176, 249 cited on silica in Knox dolomite..... 253-254

Phlogopite, importation of............. 400

Phosphates and phosphorus, papers on... 449-482

Survey publications on, list of......... 483

Phosphate-bearing rocks, description of. . 452-453

Phosphate deposits (develaped), northern

Arkansas, paper on......... 463-473

Pennsylvania, paper on ............ 474-483

western United States, paper on.... 449-462 work on.

Phosphorite, extraction of phosphorus from ....................... 47

Phosphorus, manufacture of ......... 474, 478-481 production of .................. 481-482 uses of . . . . . . . . . . . . . . . . . . . . . $482-483$

Pierre shale, analyses of .............. 238, 243 occurrence of .................. 237-238, 243

Pigeon Hill quarry, granite of, composition of ...................... 358

Pine Bar gold diggings, Snake River, Wyo., operations at............... 78-79

Pine Grove Furnace, $\mathrm{Pa}$., brick clays used at...................... 324,325 clay beds at........................ 332

Piney, Pa., clay near.................... 341, 342 Piney Mountain, Oreg., nickel deposits at. 120-127

Pinkney, Tenn., iron ores from, analyses of. 154

Piollett, Pa., clay near................... 342

Pipe clay, analyses of ..................... $\quad 272$ tests of .......................... 275
Page.

Pismo formation, diatomaceous earth in. 439,445 Plasters, materials for, work on........... 24 Survey publications on.............. 266 Platinum, occurrence of, in Snake River gravels................... 87-88

Survey publications on, list of ........ 1.29 Platteville formation, analyses of rocks in. 228,229 sections of . .................... 227-229 Plumtree, N. C., mica near............ 407, 409 Poland, Me., feldspar at............... 392 Polk Bayou limestone, description of.... 466, 473 Porter, J. T., paper by, on properties and tests of fuller's earth ........ 26i8-290

work of ............................ 24

Portland, Oreg., electric smelting at...... 212

Portland cement, cost of making.......... 244

demand for $\ldots \ldots \ldots \ldots \ldots \ldots \ldots \ldots, 232$

plant for making, cost of .............. . 244 plants for making, location of, in Western States, map showing...... 240

Survey publications on, list of ....... 245-246 work on ......................... 225-244

Potomac formation, Ga., clays of....... 304-306 Potosi Station, Wis., section of PlattevilleGalena beds near............. $\quad 229$

Potsdam sandstone, use of, in glass making 378

Potter, Clark, farm of, clay on.......... 341

Pottsville formation, clays in .......... 337, $339,345,348-349.350-351$

section of ......................... $\quad 336$

use of, for glass sand .............. 367

Powdermill Creek, N. C. mica near........ 409

Preuss Range, Idaho, phosphates in and near....................... 450

structure in....................... 454

Prince Metallic Paint Company, works of .. 436

Prince's Manufacturing Company, paint works of.

Prouty, W. F., work of............... 247

Publications of the Survey, form and character of ................... \& $8-13$

Purdue, A. H., paper by, on developed phosphate deposits in northern $A \mathrm{r}$ kansas.................... 46i3-473

work of ........................... 25

Puzzolan cement. See Cements.

Pyrite and sulphur, papers on......... 483-489

Survey publications on............. 499

Q.

Quartz, deposits of, work on............. 24

manufacture of ..................... 388

occurrence of . ....................... 406

uses of ...................... 387-397

See also Maine, pegmatites of; quart\% of.

Quartz and feldspar, papers on......... 383-399 See also Pegmatites.

Quicksilver, Survey publications on, list of . $\quad 129$ Quincy granites, shades of, cause of....... 358 R.

Ransome, F. L., cited on Silverton quadrangle, Colorado............... 26

work of ...................... 16, 17-18

Ransome, F. L., and Hillebrand, F. L., quoted on carnotite of Colorado 111 
Ransome, F. L., Cross, Whitman, and Howe, Ernest, cited on Silverton mining district.

Rapp, John, farm of, clay on.

Rattlesnake Canyon, Cal., diatomaceous

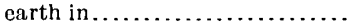

Red Gap, Ala., geologic sections near.... 136, 141 glass sand at.................... 377

Red Mountain, Ala., geologic section on.. 136-137

Reidsburg, Pa., clay near............. 342

Reigate, Fngland, fuller's earth from, analysis of......................

Republic Iron and Steẻl Company, quarry of, limestone from, analysis of.

Rhode Island, granites of, work on . . . . . 357-359

Richards, R. H., analysis by ............ 209

Richards, R. H., and Day, D. T., cited on black sands of Snake River.....

Ricketts, L. D., cited and quoted on copper ores of Wyoming...............

report by, containing references to copper deposits in Wyoming, reference to.

Riddles, Oreg., nickel ores near.......... 120-127 nickel ores near, analyses of .......... 123,124 ore deposits near, work on.

Ries, Heinrich, cited on brickmaking shale of Alabama.

cited on colloidal particles in clays .... $\quad 280$ cited on fuller's earth ................ 278 cited on plasticity of clays............ 273 tests of clay made by ............... 309,310

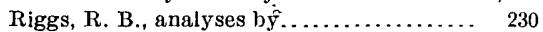

Rimersburg, Pa., clay near............ 338, 342

Riser Mountain, Ala., ores of, analyses of.. 177 prospects on, description of........ 170-171

Road metal and building stone, paper on. . 356-359 Survey publications on, list of ....... 360

Roan gneiss, mica in ................. 403-404

Robbers Cave, Nebr., glass sand at ....... 381 glass sand at, analysis of ........... 382

Rockbridge, Ohio, glass sand at........ 367,373

Rockport, Mass., granite of, composition of. 358

Rogers Bar, Columbia River, gold-bearing gravels at.................. 65-66

Rockville, Pa., clay near.............. 337

Rockwood, Colo., limestone from, analysis of ....................... 298

Rockwood formation, description of.. 135-146, 149 hematite in, use of, for paint........ 431-434 sections of . . . . . . . . . . . 136-139, 144-145

Rossi, $\Lambda$. J., cited on smelting of titaniferous iron ores.....................

Russell, I. C., cited on geology of Washington ....................... 59

Russellville district, Ala., geology of ..... 152-153 iron ores of, paper on................ 152-160 topography of ..................... 152

S.

Sage, Wyo., phosphates on.

St. Clair limestone, description

St. Joe marble, description of ...............

St. John, Orestes, cited on placer mining on Snake River.
St. Iouis, Mo., clays near, paper on ....... St. Louis and Montana Mining Company, operations of................. 32

St. Peter sandstone, use of, in glass making. $\quad 378$ Salisbury, R. D., cited on glacial deposits in Washington................. 59

Salt, Survey publications on .............. $\quad 267$

Salt Creek, Wyo., shale near, analysis of . . 236, 237 San Juan Valley, N. Mex., clay industry in.. 299 San Julian Rancho, Cal., diatomaceous earth on .................... 441

San Luis quadrangle, Cal., diatomaceous earth in .................... 445

San Miguel mine, N. Mex., geologic section near....................... 263 gypsum near, analysis of............. 264

Sand-lime brick, bibliography of ......... 258

description of ....................... 256

manufacture of, near Birmingham, Ala., paper on ................. 256-258

Sand Mountain, Ala., sandstone from, analysis of ................... 257

Sands, black, of Columbia River, Wash., mineral composition of........ 61

Sanpoil Valley, gold-bearing sands in ..... 68-69 Santa Lucia.Canyon, Cal., diatomaceous earth in ................. 441-442

Santa Margarita formation, diatomaceous earth in ................... 439, 44,

Santa Maria, Cal., diatomaceous earth near................... 444-445

Santa Rita, Cal., diatomaceous earth near................... 442-443 Santa Ynez, Cal., diatomaceous earth near. 443 Santa Ynez River, Cal., diatomaceous earth near............... 440-441, 443 Savage claim, Wyo., description of........ 424 Savannah River, Ga., glass sand at...... 378 Sawdust, etc., use of, as fuel............. 231 Sayreton, Ala., sand-lime brick plant near, notes on .................. 257-258

Schaller, W. T., analyses and tests by...... 95, $111-112,219,221,264$

Schleuter, H. C., work done in conjunction with...................... 71 Schultz, A. R., paper by, on gold deposits in Wyoming.................. 71-88 work of Schumann, Cal., diatomaceous earth near. 443-444 Seifford, - analyses by ................ 177 Senorita, N. Mex., geologic section at ....... 263 gypsum at...................... 263 Seward, Pa., clay from, analysis of ........ 348 Seward Coal Company, mine of, clay from, analysis of .................. 348

Seward County mine, Colo., ores, etc., at... 29 Shale, analyses of.................. 297, 300 Shaler, M. K., paper by, on gypsum in northwestern New Mexico......... 260-265

Shaler, M. K., and Gardner, J. H., paper by, on clays of Durango-Gallup coal field ..................... 296-302
Shales, Cambria County, Pa., paper on... $344-354$
Clarion County, Pa., paper on ...... $335-443$

Sheffield Coal and Iron Company, mines of. 157-158 ores of, analyses of .................. 154 
Page.

Sheridan, Pa., quarry near, section at..... 349

Shippensville, Pa., clay near............ 341

Siderite, occurrence of . . ........... 197, 204

origin of ........................ 198

Sierra Nacimiento, N. Mex., geology of. . 261-262 gypsum near, paper on ........... 260-265

Silurian sandstones, use of, as glass sand... 364-

365,367

Silver and gold, papers on. 26-88

Survey publications on . ............ 89-92

Silver Cliff mine, Wyoming, copper ores at. . 104

Silver Star tunnel, Colo., ores a.t......... 28

Silverton mining district, Colo., Lake Fork extension of, paper on....... 26-30

Simons, F. D., and Crampton, C. A., quoted on fuller's earth...... 284, 279-280,284

Simpson, J. H., cited on gypsum in New Mexico................ 260,265

Sioux City, Iowa, glass sand near...... . 378-379

giass sand near, analysis of .......... 382

Sisquoc, Cal., diatomaceous earth near.... 444

Sixmile Bar, Columbia River, gold-bearing gravels at.................

Sleepy Cat Mountain, Colo, geology of region at and near........... 112-113

Sligo, Pa., clay near . ............. 338, 341, 342

Sligo Fire Brick Company, clays of, analyses of .....................

Sloan, Earle, quoted on fuller's earti.......

Sloss Iron Company, quarry of, dolomite from, analysis of ............

quarry of, limestone from, analyses of. .

Sloss-Sheffield Steel and 'Iron Company, mines of....................

ores of, analyses of ..................

quarry of, limestone from, analysis of..

Smectite, analysis of. ..................

Smith, E. A., analyses by ...............

cited on rocks near Columbiana, Ala...

Smith, E. E., work done in conjunction with .................. 71,74

Smitil, G. O., cited on geology of part of

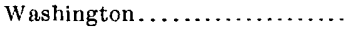

cited on mica production

note by, on a mineral prospect in Maine .....................118-119

Smith, G. O., and Calkins, F. C., cited on geology of part of Washington.

Smith, P. S., paper by, on gray iron ores of Talladega County, Ala........ 161-184

Smith, W. S. T., report by, containing references to copper deposits in $\mathrm{Wy}$ oming, reference to............

Smith, W. S. T. and Darton, N. H., cited on Guernsey formation........ 102

Smiths Fork, W yo., phosphates on. . . . . . 456-457 Snake River, gold placers on, gold values in. 83-86 gold placers on, piatinum in . . . . . . . 87-88 source of gold of . . . . . . . . . . . . . 88

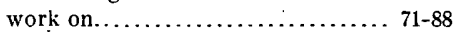

Soda, Survey publications on. ........... 267

Sonnhalter Sand and Stone Company, quarry of. ............. 373,374
Sorenson gold diggings, Snake River, operations at................... 80

Soudan mine, Minn., copper at........... 101

South Fork, I'a., clays and shales near... 350-352

South Mountain, Pa., clays of, paper on. . 322-334

map of part of ................. 327

Spechts Ferry, Iowa, section of Platteville rocks at.................... 228

Spencer, A. C., paper by, on magnetite dcposits in Pennsylvania...... 185-189

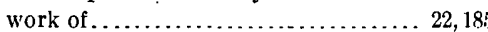

Spencer siding, Wyo., shale near, analysis of . ..................... 238

Stansbury, Howard, quoted on iron ores of Iron Mountain, Wyo......... 207

Stanton, ' $\mathbf{~ . ~ W . , ~ f o s s i l s ~ s t u d i e d ~ b y ~ . . . . . . . . . . ~} 72$

Steiger, George, analyses and tests made by ................ 114, 124, 120

Stein, Joseph L., acknowledgments to..... 93 Sterrett, D. B., paper by, on mica deposits in western North Carolina... 400-422 work of . . . . . . . . . .

Stockade Beaver Creek, Wyo., limestone near, analyses of. ......... 235-230

Stockbridge dolomite, occurrence of ........ 394 Stose, C. W., paper by, on clays of South Mountain, Pa.............. 322-334

paper by, on phosphorus ore at Mounc Holly Springs, Pa......... 474-483

work of . . . .

Stranger Creek, Columbia River, gold-bearing gravels at mouth of. ...... 67

Strasburg, Ohio, glass sand at......... 374

Strattonville, Pa., clay near............ 338,342

Structural materials, work on ........... 23-24

Sublette Range, Wyo., phosphates in ... 450,457 structure of ....................... 453

Sugar Pine Creek, Utah, phosphates on.... 455 Sullivan, E. C., analyses by ....... 209, 348, 352, 487 cited on origin of copper ores........ 105 cited on Wyoming graphite......... 427 Sulphur and pyrite, papers on......... 483-489 Survey publications on ........... 490 Sulphurdale, Utah, sulphur at and near... 483 Sunrise copper mine, W yo., output of ..... $\quad 99$ rocks and ores at .................. 99-101 Sunrise mine, Wyo., production of . . . . . . 193 Swan Lakes, Idaho, phosphates near. . . . 4 461-462 Swingle (J. S.) quarry, granite of, compositiois of . . . . . . . . . . . . . . 358 Sycamore, Ala., hematite near, analysis of.. $\quad 176$ Sylvania, Ohio, glass sand at....... 367,370-371 glass sand at, analysis of ........... 376 Sylvania sandstone, use of, for glass sand. 370-371 Symons, T. W., cited on placer mining on Columbia River, Wash .........

T.

Tallaseehatchee mine. See Mesaba mine.

Tanyard Gap, Ala., geologic section in.... 138 geologic relations and development of. 433-434 Tennessee, hematite in, mining of ...... 430-431 hematite in, use of, in paint........ 430 
Page.

Tennessee, iron ores in, occurrence of ..... 156 iron ores in, work on...............

Tennesses Coal, Iron and Railroad Company, mines of, sections of ironore seams in............... 143, 144

Tennessce Republic Company, quarry of, dolomite from, analysis of .... 253

Terre Haute, Ind., glass works at........ 368

Tertiary deposits, use of, for glass making.. 366

Thomas Fork, Wyo., phosphates on...... 457

Thompson (Horace) mine, N. C., description of .....................

Thorn Mountain mine, N. C., description of . .................. 411-412

Tin, Survey publications on, list of....... 129

Tip Top, Ky., glass sand at. . . . . . . 363,369-370 glass sand at, analysis of .......... 376

Titaniferous iron ore, impurities in, analysis of ..................... 212 occurrence of, in Wyoming ........ 206-212

Toboso, Ohio, glass sand at.......... 372-373

Toledo Stone and Glass Company, quarry of . .................... 370-371

Tomstown, Pa., clay beds at........... 325

Trenton Flint and Spar Company, mills of. 387 quarries of........................ 390

Tripoli. See Diatomaceous earth.

Truittsburg, Pa., clay near.............. 342

Trussville, Ala., glass sand near......... 377 glass sand near, analysis of. .......... 382

'Tucker, Thomas, acknowledgments to..... 190

Tungsten, Survey publications on, list of... 129

Tunnel IIollow, Utah, section in........ 455

Tuscaloosa formation, Ga., clays of . . . . . . 304-306

Tushar Mountains, geology of ........... 496

Twelvemile Creek, Utah, phosphates on ... 455

'T'winsburg, Ohio, glass sand at......... 374

\section{U.}

Uinta Mountains, Utah, work in.........

Ulrich, E. O., fossils determined by .......

Underwood mine, Pa., shale at.......... 337

Upper Mill, Pa., wavellite near.......... 475

Utah, geology of . . . . . . . . . . . . ...... 450-451 phosphates in, description and geology

of ..................... 449-454

occurrences of . . . . . . . . . . . . 454-455

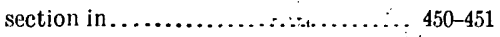

structure in. ..................... $453-454$

sulphur in. See Cove Creek, Utah.

work in, on metalliferous deposits.....

Utah Sulphur Company, mines of:.......

\section{V.}

Van Hise, C. R., cited on origin of hematite. 181 cited on pegmatites............... 419-420

Veatch, A.C., cited on Crawford Mountains structure................................. cited on Wyoming rocks.

Veatch, Otto, paper by, on kaolins and fire clays of central Georgia....... 303-314 work of..

Versailles, Mo., glass sand near. $380-381$ glass sand near, analysis of.
Virginia, iron ores of, work on......... 21-2

Von Foullon, 1I. B., analysis of nickel orc by. 123 cited on nickel content of rocks from Oregon.................. 124 cited on origin of nickel ores of Oregon. 127 paper by, on nickel ores from Oregon, reference to.................. 120

\section{W.}

Walcott, C. D., cited on Pennsylvania geol-

$$
\text { ogy ................. 322,476 }
$$

Walker Gap, Ala., geologic section in..... 137

War Eagle Creek, Ark., phosphates on.... 464

Warwick, Ohio, glass sand â.......... 374

Wasatch Range, Utah, struçure in...... 453

Washburne, C. W., work of ........... 247

Washington, gold in, work on ........... 56-70 work in, on metalliferous deposiıs .... $\quad 19$

Waterloo claim, Idaho, phosphates at . . 458-459

Waupeion, Iowa, secion of Platteville-Ga-

lena beds near............. 229

Wavellite, exiraction of phosphorus from.. 474 occurrence of ..................... 474 origin of . . . . . . . . . . . . . . .

Wayah Bald, N. C., mica near. ........ . 412-413

Wayah Bald mine, N. C., mica in . . . . . . 412-413 section in, figure showing............ 413

Wayah Gap, N. C., mica near.......... 411

Waynesville, N. C., mica near........... 409

.Weber Canyon, Utah, phosphates in. 450,454-455 section of . ....................... 454

Wektu, N. C., mica near................ 416 Weeks, F. B., and Ferrier, W. F., paper by, on phosphate deposits....... 449-462

work of.

West Quincy, Mass., granites of, composition of ................... 358

West Pembroke, Me., ore from, assay of . . . . 119

West Red Mountain, Ala., geologic sections on..................... 144-145

Westerly, R. I., granite of, composition of. 359

We ter Steel Sand Company, quarry of..... 374

Whalen Canyon, Wyo., mica near........ 423

Wheeling, Ala., quarry near, limestone from, analysis of .......... 255

White, C. A., cited on Evanston series.... 73 White Oak Mountain, Tenn., paint ore at. 433-434 White River, Ark., glass sand on......... . 378 Wickes, J. H., mine of, section at........ 350 Wigwam quarry, granite of, composition of. 358 Wild Cat, Pa., clay near................ 338 Wildwood, Ga., paint ore at.......... 431-432 paint ore at, section of .............. 432 Wiley, H. W., cited on absorptive power of clays....................... 281

cited on colloidal constituent of clay . . 281-284 Williams, F. S., quoied on Arkansas Fertilizer Company ............ 466-467

Willis, Bailey, cited on former courses of rivers in Washington......... 59

Wilmot Bar, Columbia River, gold-bearing sands at...................

Winchell, N. H., cited on copper in mines of Minnesota ................. 101

Wolcott, Ind., glass sand at......... 365,369 
Woolsey, L. H., paper by, on Lake Fork extension of Silverton mining district.

$26-30$

work of . ......................... 16

Woodward, R. W., analysis by ........... 209

Woodruff, Utah; phosphates near....... 450,455

Wyoming, cement resources of, work on . . 23

copper deposits in . . . . . . . . . . . . 93-107

geology of part of ............... 450-451

gold deposits in, work on............. 71-88

graphite in ..................... 426-428

analysis of ..................... 427

work on ...................... 25

iron ores of, work on ........... 22, 190-212

metalliferous deposits in, work on .... 19, 22

mica in ........................ $423-425$

work on...................... 24
Prge.

Wyoming, pegmatite of, micu in......... 423 phosphates in, character and geology

of ....................... 449-454

occurrences of .................. 456-457

Portland cement maserials in, work on. 232

section in ..................... 450-451

structure in................... 453-454

Y.

York Clay Company, Pr., operations of .... 330

7.

Zinc, Survey publications on, list of ...... 128

Zinc ore, occurrence of, in Maine........ 118-119

Zollicoffer Lake, Iowa, sećion of Platie-

ville rocks near.............. 228 



\title{
CLASSIFICATION OF THE PUBLICATIONS OF THE: UNITED STATES GEOLOGICAL SURVEY.
}

\author{
[Bulletin No. 315.]
}

The publications of the United States Geological Survey consist of (1) Annual Reports, (2) Monographs, (3) Professional Papers, (4) Bulletins, (5) Mineral Resources, (6) WaterSupply and Irrigation Papers, (7) Topographic Atlas of United States-folios and separate sheets thereof, (8) Geologic Atlas of United States-folios thereof. The classes numbered 2,7 , and 8 are sold at cost of publication; the others are distributed free. A circular giving complete lists can be had on application.

Most of the above publications can be obtained or consulted in the following ways:

1. A limited number are delivered to the Director of the Survey, from whom they can be obtained, free of charge (except classes 2,7 , and 8), on application.

2. A certain number are delivered to Senators and Representatives in Congress for distribution.

3. Other copies are deposited with the Superintendent of Documents, Washington, D. C., from whom they can be had at prices slightly above cost.

4. Copies of all Government publications are furnished to the principal public libraries in the large cities throughout the United States, where they can be consulted by those interested.

The Professional Papers, Bulletins, and Water-Supply Papers treat of a variety of subjects, and the total number issued is large. They have therefore been classified into the following series: A, Economic geology; B, Descriptive geology; C, Systematic geology and paleontology; D, Petrography and mineralogy; E, Chemistry and physics; F, Geography; G, Miscellaneous; H, Forestry; I, Irrigation; J, Water storage; K, Pumping water; L, Quality of water; M, General hydrographic investigations; N, Water power; O, Underground waters; $\mathrm{P}$, Hydrographic progress reports. This paper is the ninety-fifth in Series $A$, the com- plete list of which follows $(\mathrm{PP}=$ Professional Paper; $\mathrm{B}=$ Bulletin; $\mathrm{WS}=$ Water-Supply Paper):

\section{SERIES A, ECONOMIC GEOLOGY.}

B 21. Lignites of Great Sioux Reservation: Report on region between Grand and Moreau rivers, Dakota, by Bailey Willis. 1885 . 16 pp., 5 pls. (Out of stock.)

B 46. Nature and origin of deposits of phosphate of lime, by R. A. F. Penrose, jr., with introduction by N. S. Shaler. 1888 . $143 \mathrm{pp}$. (Out of stock.)

B 65. Stratigraphy of the bituminous coal field of Pennsylvania, Ohio, and West Virginia, by I. C. White. 1891. 212 pp., 11 pls. (Out of stock.)

B 111. Geology of Big Stone Gap coal field of Virginia and Kentucky, by M. R. Campbell. 1893. 106 pp., 6 pls. (Out of stock.)

B 132. The disseminated lead ores of southeastern Missouri, by Arthur Winslow. 1896. $31 \mathrm{pp.} \mathrm{(Out}$ of stock.)

B 138. Artesian-well prospects in Atlantic Coastal Plain region, by N.H. Darton. 1896.228 pp., 19 pls.

B 139. Geology of Castle Mountain mining district, Montana, by W. H. Weed and L. V. Pirsson. 1896. $164 \mathrm{pp} ., 17 \mathrm{pls}$.

B 143. Bibliography of clays and the ceramic arts, by J. C. Branner. $1896.114 \mathrm{pp.}$

B 164. Reconnaissance on the Rio Grande coal fields of Texas, by T. W. Vaughan, including a report on igneous rocks from the San Carlos coal field, by E. C. E. Lord. 1900.100 pp., 11 pls. (Out of stock.)

B 178. El Paso tin deposits, by W. H. Weed. $1901.15 \mathrm{pp} ., 1 \mathrm{pl}$

B 180. Occurrence and distribution of corundum in United States, by J.H. Pratt. 1901. 98 pp., 14 pls. (Out of stock; see No. 269.)

B 182. A report on the economic geology of the Silverton quadrangle, Colorado, by F. L. Ransome. 1901. 266 pp., 16 pls. (Out of stock.) 
B 184. Oil and gas fields of the western interior and northern Texas Coal Measures and of the Upper Cretaceous and Tertiary of the western Gulf coast, by G. I. Adams. 1901. 64 pp., 10 pls. (Out of stock.)

B 193. The geological relations and distribution of platinum and associated metals, by J. F. Kemp. 1902. 95 pp., 6 pls.

B 198. The Berea grit oil sand in the Cadiz quadrangle, Ohio, by W. T. Griswold. $1902.43 \mathrm{pp} ., 1 \mathrm{pl}$. (Out of stock.)

PP 1. Preliminary report on the Ketchikan mining district, Alaska, with an introductory sketch of the geology of southeastern Alaska, by A. H. Brooks. 1902.120 pp., 2 pls.

B 200. Reconnaissance of the borax deposits of Death Valley and Mohave Desert, by M. R. Campbell. 1902. 23 pp., 1 pl. (Out of stock.)

B 202. Tests for gold and silver in shales from western Kansas, by Waldemar Lindgren. 1902.21 pp. (Out of stock.)

PP 2. Reconnaissance of the northwestern portion of Seward Peninsula, Alaska, by A. J. Collier. 1902. 70 pp., 11 pls.

PP 10. Reconnaissance from Fort Hamlin to Kotzebue Sound, Alaska, by way of Dall, Kanuti, Allen, and Kowak rivers, by W. C. Mendenhall. 1902. 68 pp., 10 pls.

PP 11. Clays of the United States east of the Mississippi River, by Heinrich Ries. 1903.298 pp., 9 pls. (Out of stock.)

P. 12. Geology of the Globe copper district, Arizona, by F. L. Ransome. 1903.168 pp., 27 pls.

B 212. Oil fields of the Texas-Louisiana Gulf Coastal Plain, by C. W. Hayes and William Kennedy. 1903. $174 \mathrm{pp} ., 11 \mathrm{pls.}$ (Out of stock.)

B 213. Contributions to economic geology, 1902; S. F. Emmons and C. W. Hayes, geologists in charge. 1903. 449 pp. (Out of stock.)

PP 15. The mineral resources of the Mount Wrangell district, Alaska, by W. C. Mendenhall and F. C. Schrader. 1903.71 pp., 10 pls.

B 218. Coal resources of the Yukon, Alaska, by A. J. Collier. 1903. 71 pp., 6 pls.

B 219. The ore deposits of Tonopah, Nevada (preliminary report), by J. E. Spurr. 1903.31 pp., 1 pl. (Out of stock.)

P.P 20. A reconnaissance in northern Alaska in 1901, by F. C. Schrader. 1904.139 pp., 16 pls.

PP 21. Geology and ore deposits of the Bisbee quadrangle, Arizona, by F. L. Ransome. 1904.168 pp., 29 pls.

B 223. Gypsum deposits in the United States, by G. I. Adams and others. 1904. 129 pp., 21 pls. (Out of stock.)

PP 24. Zinc and lead deposits of northern Arkansas, by G. I. Adams. 1904. 118 pp., 27 pls.

PP 25. Copper deposits of the Encampment district, Wyoming, by A. C. Spencer. 1904.107 pp., 2 pls. (Out of stock.)

B 225. Contributions to economic geology, 1903, by S. F. Emmons and C. W. Hayes, geologists in charge. 1904. 527 pp., 1 pl. (Out of stock.)

PP 26. Economic resources of the northern Black Hills, by J. D. Irving, with contributions by S. F. Emmons and T. A. Jaggar, jr. 1904. '222 pp., 20 pls.

PP 27. A geological reconnaissance across the Bitterroot Range and Clearwater Mountains in Montana and Idaho, by Waldemar Lindgren. 1904. 123 pp., 15 pls.

B 229. Tin deposits of the York region, Alaska, by A. J. Collier. 1904. 61 pp., 7 pls.

B 236. The Porcupine placer district, Alaska, by C. W. Wright. 1904.35 pp., 10 pls.

- B 238. Economic geology of the Iola quadrangle, Kansas, by G. I. Adams, Erasmus Haworth, and W. R. Crane. 1904.83 pp., 11 pls.

B 243. Cement materials and industry of the United States, by E. C. Eckel. 1905.395 pp., 15 pls.

B 246. Zinc and lead deposits of northwestern Illinois, by H. Foster Bain. , 1904.56 pp., 5 pls.

B 247. The Fairhaven gold placers of Seward Peninsula, Alaska, by F. H. Moffit. 1905.85 pp., 14 pls.

B 249. Limestones of southeastern Pennsylvania, by F. G. Clapp. 1905.52 pp., 7 pls.

B 250. The petroleum fields of the Pacific coast of Alaska, with an account of the Bering River coal deposits, by G. C. Martin. 1905. 65 pp., 7 pls.

B 251. 'The gold placers of the Fortymile, Birch Creek, and Fairbanks regions, Alaska, by L. M. Prindle. 1905. 89 pp., 16 pls.

WS 117. The lignite of North Dakota and its relation to irrigation, by F. A. Wilder. $1905 . \quad 59$ pp., 8 pls.

PP 36. The lead, zinc, and fluorspar deposits of western Kentucky, by E. O. Ulrich and W. S. T. Smith. 1905. 218 pp., 15 pls.

PP 38. Economic geology of the Bingham mining district, Utah, by J. M. Boutwell, with a chapter on areal geology, by Arthur Keith, and an introduction on general geology, by S. F. Emmons. 1905. 413 pp., 49 pls.

PP 41. Geology of the central Copper River region, Alaska, by W. C. Mendenhall. 1905. 133 pp., 20 pls.

B 254. Report of progress in the geological resurvey of the Cripple Creek district, Colorado, by Waldemar Lindgren and F. L. Ransome. 1904. $36 \mathrm{pp}$.

B 255. The fluorspar deposits of southern Illinois, by H. Foster Bain. 1905.75 pp., 6 pls. (Out of stock.) 
L 256. Mineral resources of the Elders Ridge quadrangle, Pennsylvania, by R. W. Stone. 1905.86 pp., 12 pls.

B 269. Report on progress of investigations of mineral resources of Alaska in 1904, by A. H. Brooks and others. $1905.196 \mathrm{pp} ., 3 \mathrm{pls}$.

B 260. Contributions to economic geology, 1904; S. F. Emmons and C. W. Hayes, geologists in charge. 1905. 620 pp., 4 pls.

B 261. Preliminary report on the operations of the coal-testing plant of the United States Geological Survey at the Louisiana Purchase Exposition, St. Louis, Mo., 1904; J. W. Parker, J. A. Holmes, and M. R. Campbell, committee in charge. 1905. $172 \mathrm{pp.}$ (Out of stock.)

B 263. Methods and cost of gravel and placer mining in Alaska, by C. W. Purington. 1905. 273 pp., 42 pls. (Out of stock.)

PP 42. Geology of the Tonopah mining district, Nevada, by J. E. Spurr. 1905.295 pp., 24 pls.

PP 43. The copper deposits of the Clifton-Mlorenei district, Arizona, by Waldemar Lindgren. 1905. 375 pp., 25 pls.

B 264. Record of deep-well drilling for 1904, by M. L. Fuller, E. F. Lines, and A. C. Veatch. 1905. $106 \mathrm{pp}$.

B 265. Geology of the Boulder district, Colorado, by N. M. Fenneman. $1905.101 \mathrm{pp}$.; 5 pls.

B 267. The copper deposits of Missouri, by H. Foster Buin and E. O. Ulrich. $1905.52 \mathrm{pp} ., 1 \mathrm{pl}$.

B 269. Corundum and its occurrence and distribution in the United States (a revised and enlarged edition of Bulletin No. 180), by J. H. Pratt. 1906.175 pp., 18 pls.

PP 48. Report on the operations of the coal-testing plant of the United States Geological Survey at the Louisiana Purchase Exposition, St. Louis, Mo., 1904; E. W. Parker, J. A. Holmes, M. R. Campbell, committee in charge. 1906. (In 3 parts.) 1492 pp., 13 pls.

B 275. Slate deposits and slate industry of the United States, by T. N. Dale, with sections by E. 0 . Eckel, W. F. Hillebrand, and A. T. Coons. 1906.154 pp., 25 pls.

PP 49. Geology and mineral resources of part of the Cumberland Gap coal field, Kentucky, by G. H. Ashley and L. C. Glenn, in cooperation with the State Geological Department of Kentucky, C. J. Norwood, curator. 1906.239 pp., 40 pls.

B 277. Mineral resources of Kenai Peninsula, Alaska: Gold fields of the Turnagain Arm region, by F. H. Moffit; Coal fields of the Kachemak Bay region, by R. W. Stone. $1906.80 \mathrm{pp}, 18 \mathrm{pls}$. (Out of stock.)

B 278. Geology and coal resources of the Cape Lisburne region, Alaska, by A. J. Collier. 1906. 54 pp., 9 pls. (Out of stock.)

B 279. Mineral resources of the Kittanning and Rural Valley quadrangles, Pennsylvania, by Charles Butts. 1906. $198 \mathrm{pp} ., 11 \mathrm{pls}$.

B 280. The Rampart gold placer region, Alaska, by L. M. Prindle and F. L. Hess. 1906.54 pp., 7 pls. B 282. Oil fields of the Texas-Louisiana Gulf Coastal Plain, by N. M. Fenneman. 1906. 146 pp., 11 pls.

PP 51. Geology of the Bighorn Mountains, by N. H. Darton. 1906.129 pp., 47 pls.

B 283. Geology and mineral resources of Mississippi, by A. F. Crider. 1906 . 99 pp., 4 pls.

B 284. Report on progress of investigations of the mineral resources of Alaska in 1905, by A. H. Brooks and others. $1906.169 \mathrm{pp} ., 14 \mathrm{pls}$.

B 285. Contributions to Economic Geology, 1905; S. F. Emmons and E. C. Eckel, geologists in charge. 1906. $506 \mathrm{pp} ., 13 \mathrm{pls}$. (Out of stock.)

B 286. Economic geology of the Beaver quadrangle, Pennsylvania, by L. H. Woolsey. 1906.132 pp., 8 pls.

B 287. Juneau gold belt, Alaskia, by A. C. Spencer, and A reconnaissance of Admiralty Island, Alaska, by C. W. Wright. $1906.161 \mathrm{pp} ., 27 \mathrm{pls}$.

PP 54. The geology and gold deposits of the Cripple Creek district, Colorado, by W. Lindgren and F. L. Ransome, 1906. 516 pp., 29 pls.

PP 55. Ore deposits of the Silver Peak quadrangle, Nevada, by J. E. Spurr. 1906. 174 pp., 24 pls.

B 289. A reconnaissance of the Matanuska coal field, Alaska, in 1905, by G. C. Martin. 1906. 34 pp., 5 pls.

B 290. Preliminary report on the operations of the fuel-testing plant of the United States Geological Survey at St. Louis, Mo., 1905, by J. A. Holmes. 1906. 240 pp.

B 293. A reconnaissance of some gold and tin deposits of the southern Appalachians, by L. C. Graton, with notes on the Dahlonega mines, by W. Lindgren. 1906.134 pp., 9 pls.

B 294. Zinc and lead deposits of the upper Mississippi Valley, by H. Foster Bain. 1906. 155 pp., 16 pls. B 295. The Yukon-Tanana region, Alaska, description of Circle quadrangle, by L. M. Prinale. 1906. 27 pp., 1 pl.

B 296. Economic geology of the Independence quadrangle, Kansas, by Frank C. Schrader and Erasmus Haworth. $1906.74 \mathrm{pp} .6 \mathrm{pls}$.

B 297. The Yampa coal field, Routt County, Colo., by N. M. Fenneman, Hoyt S. Gale, and M. R. Campbell. 1906. 96 pp., 9 pls.

- B 298. Record of deep-well drilling for 1905, by Myron L. Fuller and Samuel Sanford. 1906. 299 pp.

B 300 . Economic geology of the Amity quadrangle in eastern Washington County, Pa., by Frederick G. Clapp. 1907.145 pp., 8 pls.

B 303. Preliminary account of Goldfield, Bullfrog, and other mining districts in southern Nevadn, by F . L. Ransome, with notes on the Manhattan district, by G. H. Garrey and W. H. Emmans. 1906. 98 pp., 5 pls.

Bull. 315-07-33 
B 304. Oil and gas flelds of Greene County, Pa., by Ralph W. Stone and Frederick G. Clapp. 1906. $110 \mathrm{pp} ., 3 \mathrm{pls}$.

PP 56. Geography and Geology of a portion of southwestern Wyoming, with special reference to coal and oil, by A. C. Veatch. 1907. - pp., 26 pls.

B 308. A geologic reconnaissance in south western Nevada and eastern California, by S. H. Ball, 1907. 218 pp., 3 pls.

B 309. The Santa Clara Valley, Puente Hills, and Los Angeles oil districts, southern California, by G. H. Eldridge and Ralph Arnold. 1907. - pp., 41 pls.

B 312. The interaction between minerals and water solutions, with special reference to geologic phenomena, by E. C. Sullivan. $1907.69 \mathrm{pp}$.

B 313. The granites of Maine, by T. Nelson Dale, with an introduction by G. O. Smith. 1907. - pp., 14 pls.

B 314. Report of progress of investigations of mineral resources of Alaska in 1906, by A. H. Brooks and others. 1907. - pp., 4 pls.

B 315. Contributions to economic geology, 1906, Part I: Metals and nonmetals, except fuels; S. F. Emmons and E. C. Eckel, geologists in charge. 1907. 504 pp., 4 pls.

Correspondence should be addressed to

The Director,

United States Geological Surver,

APRIL, 1907.

\section{Washington, D. C.}

0 